\title{
Back Arc Extension in the Okinawa Trough
}

\author{
Jean-Claude Sibuet, ${ }^{1}$ Jean Letouzey, ${ }^{2}$ Florence Barbier, ${ }^{3}$ Jacques Charvet, ${ }^{4}$ Jean-Paul Foucher, ${ }^{1}$ \\ Thomas W. C. Hilde, ${ }^{5}$ Masaaki Kimura, ${ }^{6}$ Chiao Ling-Yun, ${ }^{7}$ Bruno Marsset, ${ }^{8}$ \\ Carla Muller, ${ }^{9}$ and Jean-François Stéphan ${ }^{8}$
}

\begin{abstract}
The Okinawa Trough, lying to the east of China, is a back arc basin formed by extension within continental lithosphere behind the Ryukyu trench-arc system. Middle to late Miocene uplift, associated with normal faulting of the initially adjacent Ryukyu nonvolcanic arc and the Taiwan-Sinzi folded belt, corresponds to the first rifting phase. The timing of rifting is supported by the presence of marine sediments of corresponding age drilled in the northern Okinawa Trough. The rifting occurred after a major early Miocene change in the motion of the Philippine plate with respect to Eurasia and ceased during the Pliocene. A second rifting phase started about $2 \mathrm{~m} . y$. ago, at the Plio-Pleistocene boundary and has continued until the present time. It has proceeded to a more advanced stage in the middle and southern Okinawa Trough than it has farther north. Detailed bathymetric (Sea Beam), seismic reflection, and magnetics data collected during the POP 1 cruise of the R/V Jean Charcot reveal the principal features of the extensional processes. The back arc spreading phase started very recently in the southern and middle Okinawa Trough, as exemplified by several en échelon and, in some cases, overlapping active, central graben oriented $\mathrm{N}^{\circ} 0^{\circ} \mathrm{E}-\mathrm{N} 80^{\circ} \mathrm{E}$. Some of these depressions are intruded by volcanic ridges of fresh back arc basalt with associated large magnetic anomalies. Transform faults between these en échelon active rifts are not obvious. We suggest that the major part of the southern Okinawa Trough is underlain by a thinned continental crust and that except for the system of en échelon rifts of the southern Okinawa Trough, the back arc basin oceanic domain is limited to a width of a few tens of kilometers or less in the axial portion of the trough. The system of axial back arc volcanic ridges that occur in the rifts ends at the latitude of Okinawa Island whereas active volcanoes in the Ryukyu arc occur only north of Okinawa Island. We refer to this transition between active arc and back arc volcanism as the volcanic arc-rift migration phenomenon (VAMP). Globally, back arc volcanism propagated from the southern Okinawa Trough to the Okinawa VAMP area. Rifting continues to occur in the northern Okinawa Trough but is not yet accompanied by associated volcanism. The Okinawa VAMP area is characterized by a series of parallel basaltic ridges oriented $\mathrm{N} 75^{\circ} \mathrm{E}$ with associated linear magnetic anomalies characteristic of dyke intrusions. We suggest that the formation of the back arc oceanic domain took place along the axial back arc extensional zone trending $N 75^{\circ} \mathrm{E}$ and that this zone presently ends at the southern extremity of the active volcanic chain. The initial phase of formation of back arc basin oceanic crust is non-steady state and is characterized by the lack of a developed fracture zone pattern. The termination of the VAMP area in the direction of the volcanic zone of the arc is consistent with the suggestion of Molnar and Atwater that the volcanic arc is a fundamental line of weakness which determines where initial back arc spreading occurs. Apparently, back arc extension initially occurred within the continental lithosphere located westward of the Ryukyu arc, along its whole length, but the subsequent back arc volcanism was initiated in the southernmost portion of the region and then moved northward. This migration was accompanied by the shutting down of volcanic activity along the abandoned portions of the arc. It is this transfer of volcanism that we call the VAMP process. Thus arc and back arc basin volcanism seem to be associated in such a manner that spreading tends to migrate simultaneously with a cessation in volcanic activity along the arc. This interplay of arc and back arc activity is probably linked to changes in the parameters of plate convergence. Since the plate motion in the Phillippine sea is oblique to the trench at least in the southern part of the Okinawa Trough, we suggest that the oblique resisting force applied to the edge of the overriding plate engenders the development of en échelon extensional features within and behind the arc. The motion of the Ryukyu platelet witk respect to Eurasia is consequently an extensional strike-slip motion trending roughly parallel to the Okinawa Trough.
\end{abstract}

\section{INTRODUCTION}

The Okinawa Trough, a back arc basin located behind the Ryukyu trench and Ryukyu islands, extends from the Ilan

\footnotetext{
${ }^{1}$ Institut Français de Recherche pour l'Exploitation de la Mer, Centre de Brest, Brest, France.

${ }^{2}$ Institut Français du Pétrole, Rueil-Malmaison, France.

${ }^{3}$ Laboratoire de Géodynamique, Paris, France.

${ }^{4}$ Sciences de la Terre, Université d'Orléans, Orléans, France.

${ }^{5}$ Geodynamics Research Institute, Texas A\&M University, College Station.

${ }^{6}$ Unıversity of the Ryukyus, Nishihara, Okinawa, Japan.

${ }^{7}$ Institute of Oceanography, National Taiwan University, Taipei, Taiwan.

${ }^{8}$ Groupement d'Intérêt Scientifique, Océanologie et Dynamique, Université de Bretagne Occidentale, Brest, France.

${ }^{9}$ Ruell-Malmaison, France.

Copyright 1987 by the American Geophysical Union.

Paper number 6B6016.

0148-0227/87/006B-6016\$05.00
}

Plain in northern Taiwan to the shallow sea southwest of Kyushu (Figure 1). Overall the graben of the Okinawa Trough is $60-100 \mathrm{~km}$ wide in the south and reaches a maximum width of $230 \mathrm{~km}$ in the north (Figure 1). The maximum water depth approaches $2300 \mathrm{~m}$ in the southern Okinawa Trough and progressively decreases to about $200 \mathrm{~m}$ in its northern portion.

From China to the Philippine sea, the continental margin of east China is believed to be built of a series of margin-parallel rift basins formed by back arc spreading or continental extension [Wageman et al., 1970; Jin et al., 1983] and completely filled with sediment [Emery et al., 1969] except for the Okinawa Trough. The general northeast-southwest zonal distribution of structural ridges and basins is supported by the geomagnetic anomaly map of Wageman et al. [1970]. Each basin is separated by buried ridges which may represent rifted segments of the proto-Ryukyu arcs [Jin et al., 1983] or portions of continental crust. The youngest of these possible remnant features is the Taiwan-Sinzi folded belt which forms a structural barrier between the basin of the East China Sea and 


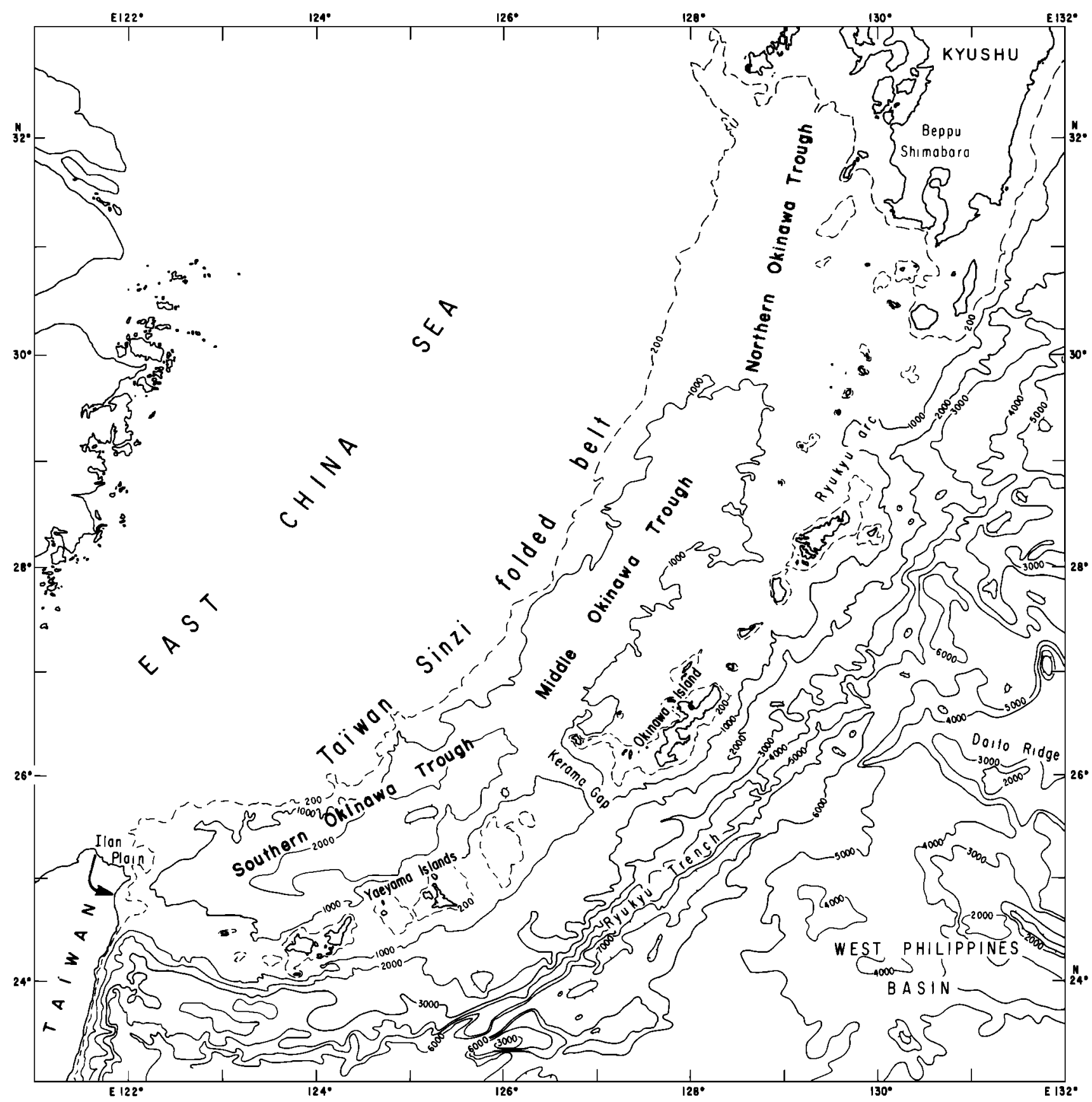

Fig. 1. Location map of Okinawa Trough, Ryukyu arc, and surrounding areas.

the Okinawa Trough. This ridge is composed of intensively folded and faulted Paleogene and Neogene sediments. Miocene andesitic igneous rocks crop out west of southern Kyushu in the northern portion of the Taiwan-Sinzi folded belt but have not been recovered elsewhere within this belt. Nevertheless, most of the Miocene volcanics of the arc are observed on the Ryukyu side which means that the Okinawa Trough was formed by extension within the east China continental lithosphere behind the Ryukyu trench-arc system.

The Ryukyu arc is composed of a nonvolcanic outer arc forming the main island chain extending from Taiwan to Kyushu and a volcanic inner arc. The pre-late Miocene substratum of the nonvolcanic arc from Yaeyama Islands to Kyushu is the prolongation of the geological outer and inner zones of southwest Japan [e.g., Charvet and Fabbri, 1987] and represents an elongated strip of the Asian continental margin, with Paleozoic and Cenozoic sediments "drifted" into place by the opening of the back arc basin. Most of the seismic activity occurs along the Wadati-Benioff zone dipping northwest from the Ryukyu Trench beneath the Ryukyu arc and Okinawa Trough to depths between 200 and $300 \mathrm{~km}$ [Katsumata and Sykes, 1969; Shiono et al., 1980]. The location of the volcanic inner arc is fixed relative to the $100-\mathrm{km}$ focal depth of the Wadati-Benioff zone [Shiono et al., 1980].

Within the Okinawa Trough, shallow seismicity is also high but scattered [Eguchi and Uyeda, 1983]. Free air gravity data suggest continental densities and thicknesses for most of the region but also indicate a general thinning beneath the Okin- 
awa Trough [Honza, 1976]. Computation of the depth to the Moho from the Bouguer data indicates a crustal thickness of $15 \mathrm{~km}$ in the southern trough increasing to $25 \mathrm{~km}$ in the northern trough and to $30 \mathrm{~km}$ beneath the East China Sea [Jin et al., 1983]. Seismic refraction studies by Murauchi et al. [1968] and Lee et al. [1980] confirm that the velocity structure and crustal thickness of the Okinawa Trough is continental in character except in its southern part where mantle velocities recorded at a depth of about $15 \mathrm{~km}$ are evidence, but not proof, of oceanic structure. Heat flow [Yasui et al., 1970; Watanabe et al., 1977; Lee et al., 1980; Lu et al., 1981] is very high, particularly in the middle and southern Okinawa Trough, but there is a wide dispersion of values from an average of $120 \mathrm{~mW} / \mathrm{m}^{2}$ in the southern trough to as high as $400 \mathrm{~mW} / \mathrm{m}^{2}$. Yasui et al. [1970] suggested that the high heat flow values are associated with shallow igneous intrusions.

Wageman et al. [1970] were the first to establish the tectonic origin of the Okinawa Trough based on their observation that the slopes of the trough were formed by a series of listric or normal faults; they estimated that the trough was created during the Neogene. Herman et al. [1978] suggested a late Pliocene opening based on the evidence of a dredge haul reported by Honza [1976]. Later on, Kimura [1985] and Letouzey and Kimura [1985] established the first detailed structural maps for the whole Okinawa Trough and dated the main opening of the trough to be at the Plio-Pleistocene boundary. Lee et al. [1980] suggested a three-phase model to explain the development of the Okinawa Trough: a "doming" phase due to thermal expansion induces uplift and erosion and is followed by tension in the brittle continental crust. Normal faulting and crustal extension, termed the "rifting" phase, continue until fault block rotation reaches an extreme limit and is replaced by the "spreading" phase of igneous intrusions.

Sea Beam records and geophysical data collected during the POP 1 cruise of the $R / V$ Jean Charcot in the Okinawa Trough (September-October 1984) reveal important features of the different phases of extension (Plate 1 and Figures 2 and 3) which provide constraints on models of back arc basin formation which have not been previously documented. (Plate 1 is shown here in a reduced version. See folded in pocket map at the back of this issue.)

\section{Geological and Geophysical Evidence for Main Tensional Phases}

\section{First Rifting Phase}

On the eastern side of the trough, the pre-late Miocene substratum occurs in the outer and southwestern zones of Kyushu, Shikoku, and Honshu in the middle and north Ryukyu islands and in the area adjacent to Taiwan. It is probably present within the inner zones of the main islands of Japan and around the southern islands of the Yaeyama archipelago [Charvet and Fabbri, 1987]. Basement of the middle and north islands is composed of slightly metamorphosed Mesozoic sediments and reworked late Paleozoic rocks (Sambosan olistrostrome) which are overlain by Cretaceous to early Miocene sediments. These sediments are interpreted as a complex tectonic pile [Charvet and Fabbri, 1987] emplaced during the northward subduction of the Philippine sea plate and prior to a northwestward change in the subduction direction with respect to Eurasia in the early Miocene [e.g., Le
Pichon et al., 1985]. Before the late Miocene, a strong erosional event marked by a sharp angular unconformity affected the whole island arc and forearc terrain [Letouzey and Kimura, 1985]. This unconformity establishes the existence of subaerial to aerial conditions during this time.

Pre-late Miocene littoral sandstones and conglomerates intercalated with thin coal beds [Sun, 1981] are found in the Taiwan-Sinzi folded belt, an elongated structure parallel to the Okinawa Trough and located on its northwest side. These deposits are interpreted as terrigenous sediments laid down on the continental side of the arc during the early to middle Miocene. In the middle and northern parts of the belt the regional late middle Miocene unconformity cuts across them [Letouzey and Kimura, 1986].

These observations suggest that after a change in the motion of the Philippine sea plate with respect to Eurasia during the early Miocene, general uplift and faulting affected the Ryukyu arc and the Taiwan-Sinzi folded belt. The uplift ended in the middle or late Miocene [Letouzey and Kimura, 1985]. For Lee et al. [1980] it is associated with the doming phase due to thermal expansion of the mantle soon after the subduction started. Yet late Miocene marine sediments have been drilled in the northern Okinawa Trough and the interpretation of multichannel seismic lines suggests that marine sediments could be at least of middle Miocene to lowermost late Miocene age [Letouzey and Kimura, 1985]. There is also no evidence of erosion during the late Miocene in the northern Okinawa Trough. These arguments suggest that the rifting phase started during middle to late Miocene and that the Okinawa Trough began to form synchronously with the uplift which generated the shoulders that flank the rift.

\section{Second Rifting Phase}

Kimura [1985] proposes that the second rifting phase in the Okinawa Trough began in the early Pleistocene after 5 m.y. of cessation of tectonic activity. In fact, the large tectonic activity which has been occurring since the Plio-Pleistocene limit only allows us to suggest that the late Miocene-Pliocene tectonic activity was weaker. The northern part of the trough is presently considered to be still in the rifting stage. Sedimentary deposits here are up to $8 \mathrm{~km}$ thick and were intensely faulted at the time of the Plio-Pleistocene transition. The lower part of the section probably includes a Miocene and perhaps Paleogene sequence. Tilted fault blocks which include Pliocene sediments are present over the whole northern Okinawa Trough. Similar fault blocks with Pliocene sediments in their upper part also grew along faults facing the axis of the middle part of the trough, both on the southeastern flank and near Okinawa Island [Letouzey and Kimura, 1985]. On the east China continental margin in the southern part of the trough, the Plio-Pleistocene unconformity is normally faulted, and this marks the last important phase in the evolution of the present-day morphology of the margin. Thus the major rifting phase started $2 \mathrm{~m}$.y. ago at the Plio-Pleistocene boundary, about $5 \mathrm{~m} . y$. after the first rifting phase ceased in the late Miocene. According to Lee et al. [1980] and Kimura [1985], if the back arc basin oceanic crust was emplaced as early as 2 m.y. ago in the southern Okinawa Trough, then the duration of the rifting phase which affected the southern East China Sea margin near Taiwan would be extremely short (less than a hundred thousands years) compared to the several tens of 
BATHYMETRIC MAP OF THE OKINAWA TROUGH

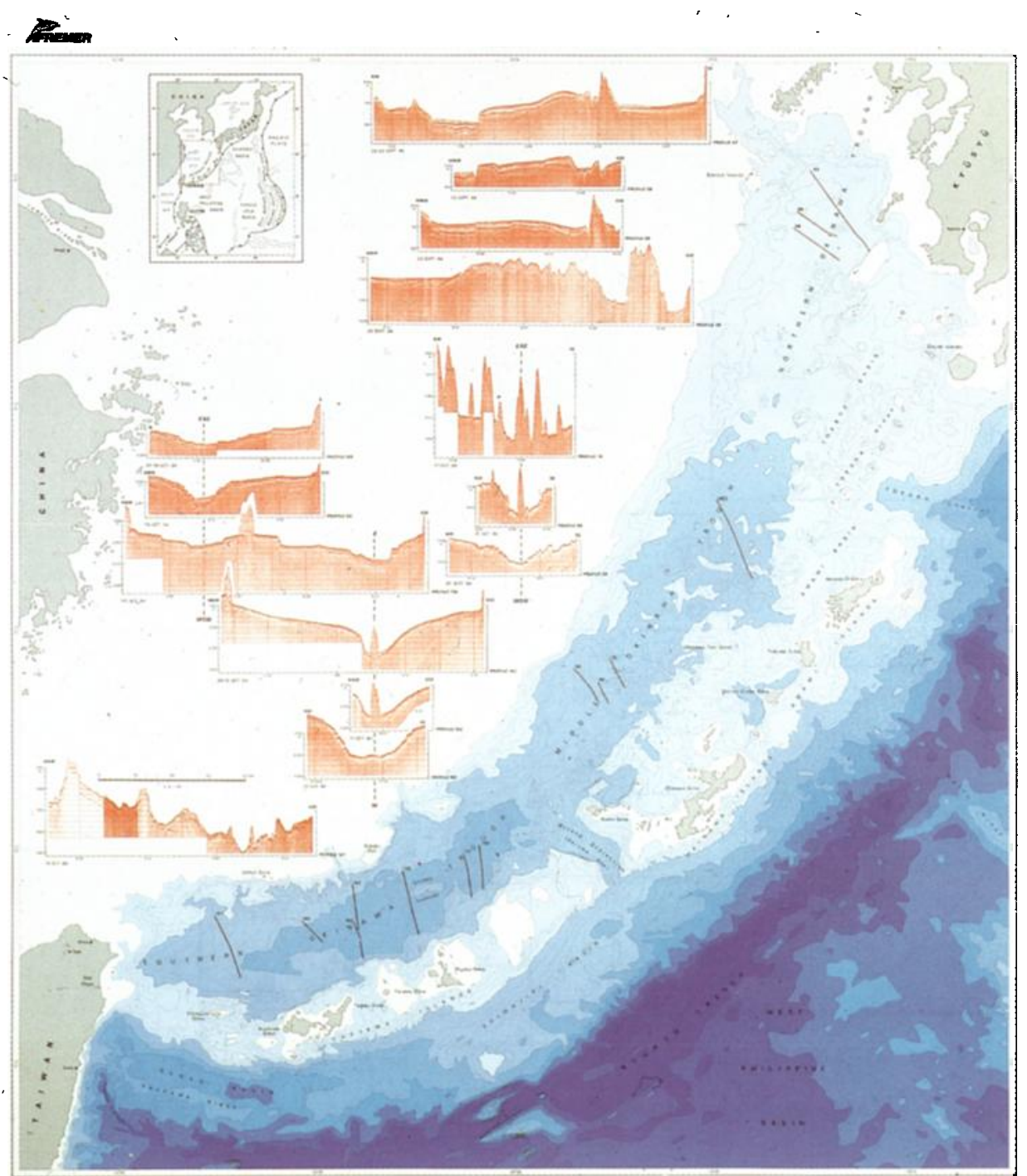

Plate 1. Bathymetric map of the Okinawa Trough. See legend and origin of data on the folded map. (This is a reduced version of the folded in pocket map at the back of this issue). 


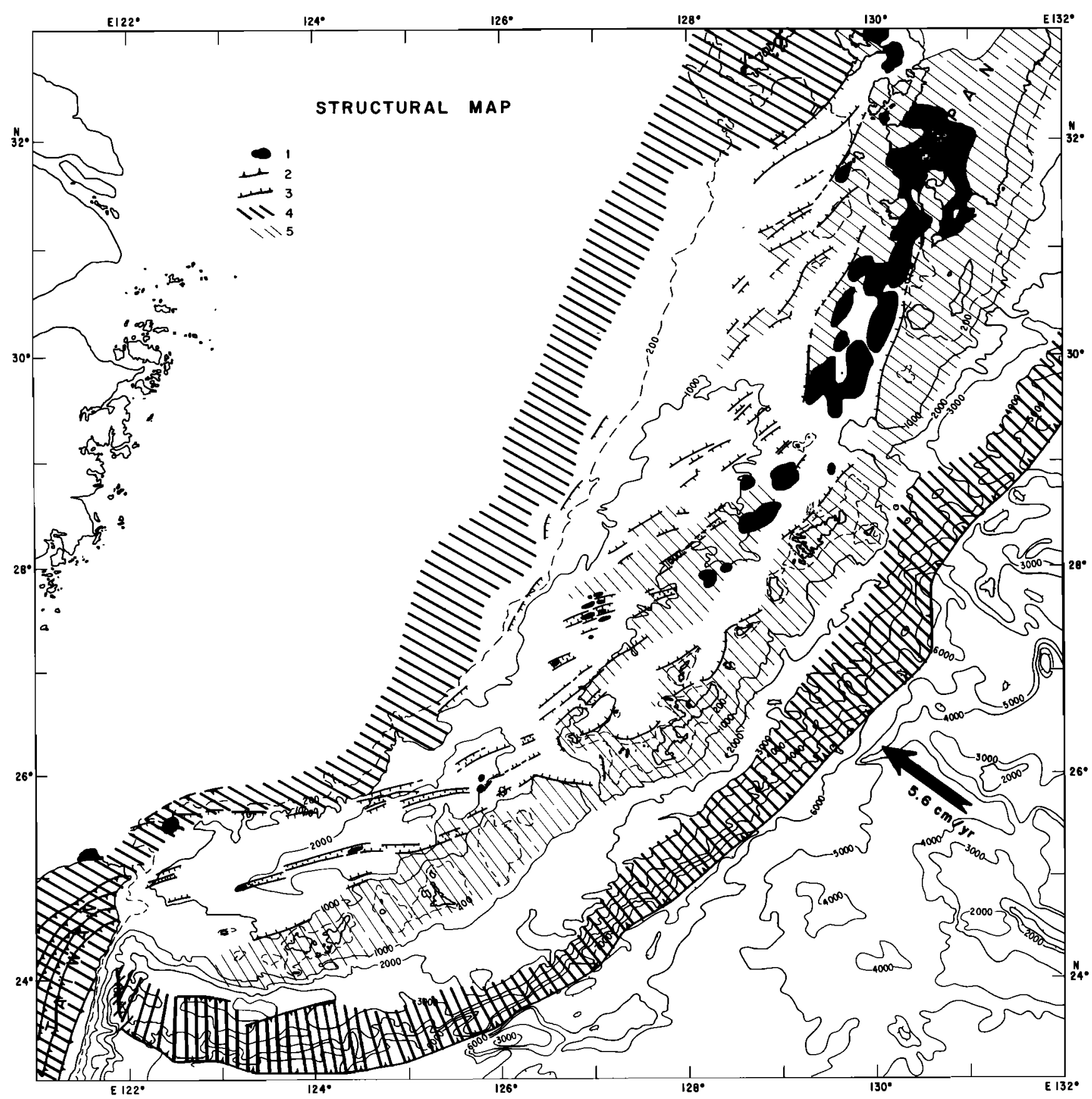

Fig. 2. Geological and structural map of the Okinawa Trough established from available seismic data (Letouzey and Kimura [1985] and POP I R/V Jean Charcot cruise). 1, present-day arc volcanism; 2, trench axis; 3, normal faults; 4, trench slopes and accretionary complex; Taiwan-Sinzi folded belt; 5 , structural highs.

millions years commonly observed on passive continental margins. We elaborate on this point in a later section.

\section{Back Arc Basin Spreading}

In the southern Okinawa Trough, refraction data clearly show three layers: a sedimentary layer with velocities ranging from 2.0 to $3.0 \mathrm{~km} / \mathrm{s}$ overlying a $4.6-5.2 \mathrm{~km} / \mathrm{s}$ layer about 2 $\mathrm{km}$ thick which in turn overlies a $5.5-6.0 \mathrm{~km} / \mathrm{s}$ layer about 4-6 $\mathrm{km}$ thick [Hayes et al., 1978; Lee et al., 1980; Kimura, 1985]. Lee et al. [1980] and Kimura [1985] suggest that this 5.5-6.0 $\mathrm{km} / \mathrm{s}$ layer, absent in the northern Okinawa Trough, could be composed of volcanics. Beneath this $5.5-6.0 \mathrm{~km} / \mathrm{s}$ layer is a 6-km-thick layer with velocities ranging from 6.4 to $7.2 \mathrm{~km} / \mathrm{s}$ atop the upper mantle (velocity $8.2 \mathrm{~km} / \mathrm{s}$ ) at about $16 \mathrm{~km}$ depth. These data suggest the presence of a crust which has velocities similar to, but twice the total thickness of, oceanic crust. The refraction data rather suggest that thinned continental crust underlies the major part of the southern Okinawa Trough.

In the middle Okinawa Trough, at the latitude of Okinawa Island, a recent seismic refraction experiment [Uyeda et al., 1985a] also shows the presence of a $6.0 \mathrm{~km} / \mathrm{s}$ layer about $5 \mathrm{~km}$ thick above a $6.8 \mathrm{~km} / \mathrm{s}$ layer which probably corresponds to the lower crust. A $2-\mathrm{km}$-thick sedimentary layer overlies the $6.0 \mathrm{~km} / \mathrm{s}$ layer. These results suggest that the crust of the middle and southern parts of the Okinawa Trough seems to 


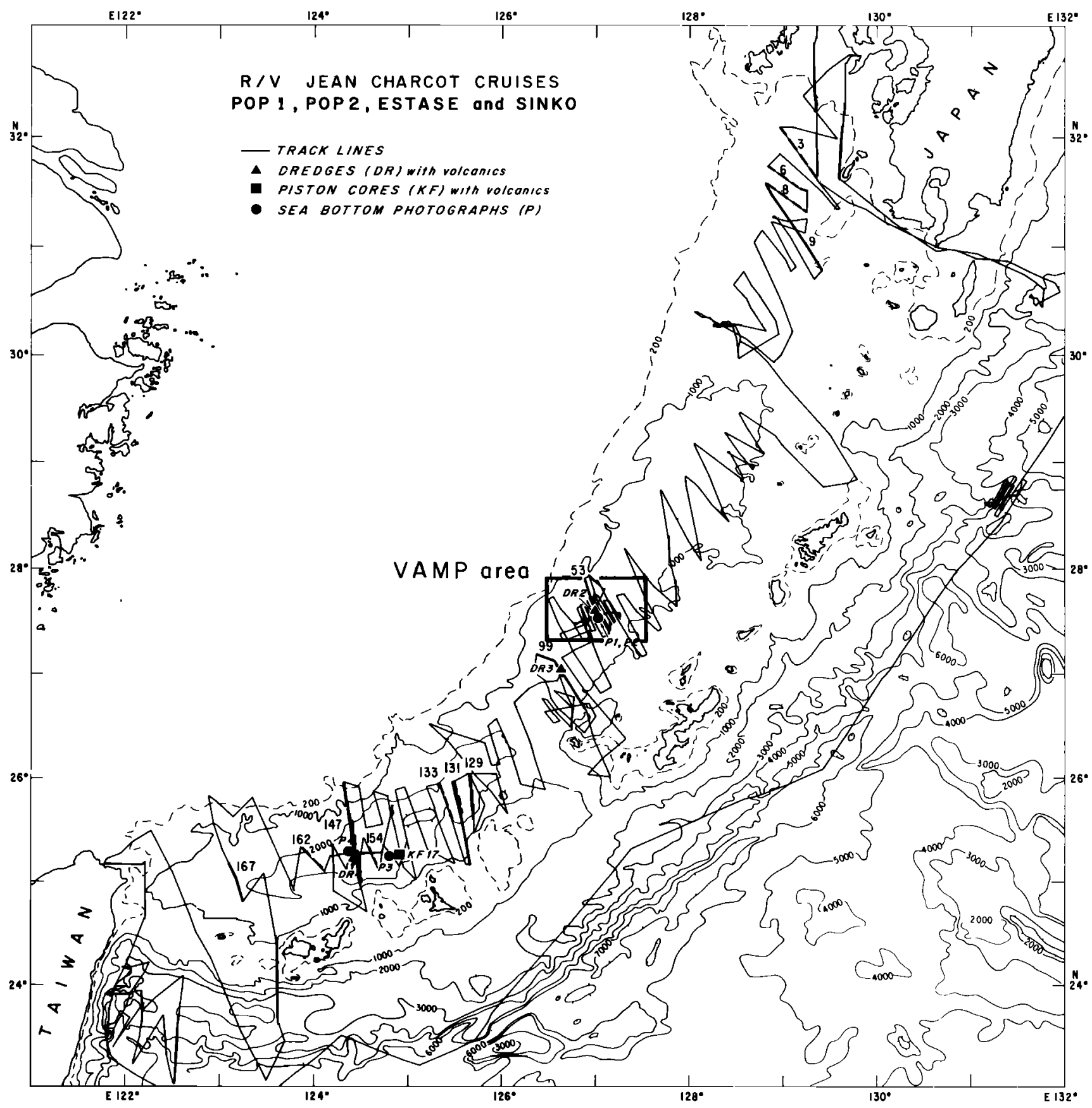

Fig. 3. Track chart of POP 1 (Okinawa Trough), POP 2 (East Taiwan), ESTASE (south Japan), and SINKO (Ryukyu Trench) cruises of R/V Jean Charcot.

be of similar composition except for the absence of the 4.6-5.2 $\mathrm{km} / \mathrm{s}$ layer in the middle section. Consequently, the presence of a thinned continental crust cannot be excluded [ $U$ yeda et al., 1985a]. Here, in the middle Okinawa Trough, a series of volcanic ridges may be interpreted as intrusions through thinned continental crust. In contrast, the crust in the northern Okinawa Trough is everywhere continental and still at the stage of thinning.

Evidence for the presence of back arc oceanic crust in the southern and middle Okinawa Trough is the existence of linear magnetic anomalies (Lee et al. [1980] and this study) of short-wavelength $(10-20 \mathrm{~km})$ and high-amplitude (200-300 $\mathrm{nT}$ ) associated with the present-day, axial back arc volcanism. Longer-wavelength $(20-30 \mathrm{~km})$ and lower-amplitude $(<100$
nT) magnetic lineations exist over the remaining part of the southern back arc basin, where the basement is often buried below more than $2 \mathrm{~km}$ of sediment. The number of cycles of magnetic anomalies in the trough is too small (two to three cycles) to give confidence in correlations with the geomagnetic reversal time scale. Nevertheless, it has been suggested by reversal time scale modeling of the low-amplitude anomalies [Lee et al., 1980; Vander Zouwen, 1985; Kimura, 1985] that seafloor spreading started about $2 \mathrm{~m}$.y. ago and ceased about 0.5 m.y. ago. This point will be debated in a later section. In the southern Okinawa Trough, the high-amplitude axial anomaly, which corresponds to a normal polarity event, is clearly associated with a present-day phase of extension and associated volcanism. 


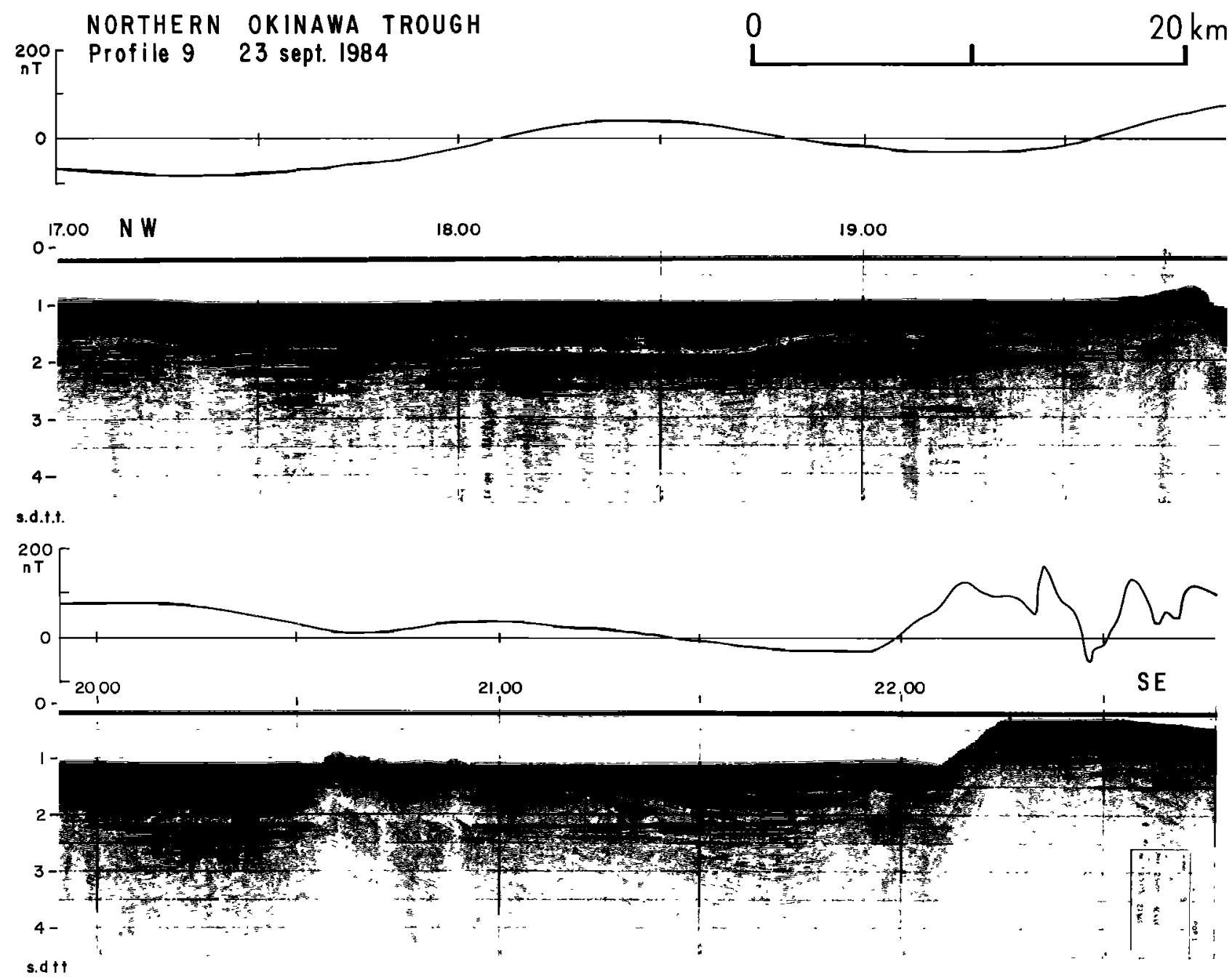

Fig. 4. Examples of Pho-Pletstocene tilted fault block geometry in the northern Okinawa Trough: IFREMER, highspeed (10 knots), single-channel seismic profile 9 and magnetic anomaly profile; location shown in Figure 3 . Vertical exaggeration $\times 3$.

\section{Geometry of Deformation Associated With Extensional Tectonics}

\section{Northern Okinawa Trough}

Because the extension in the Okinawa Trough occurred within the continental crust located just behind the volcanic belt, it is important to compare the extensional features of back arc basin formation with the tilted fault block geometry associated with ordinary extensional or rifted margins. A type example is that of the northern Bay of Biscay margin where horsts, graben, and tilted fault blocks are buried beneath a thin sedimentary cover which has been only slightly affected by postrifting tectonics [Montadert et al., 1979; Le Pichon and Sibuet, 1981]. In order to account for the large amount of extension that appears to have occurred there (as much as 10 times), Foucher et al. [1982] have suggested that there were two rifting phases: first, a Permian to Lias tensional phase, which led to the formation of a depression partly filled with Jurassic sediments along the present-day northern Bay of Biscay margin, and second, a Neocomian phase of extension which affected this preexisting basin. Based on this example, the well-known tilted fault block geometry seems to be clearly expressed only if a thick sedimentary cover exists to record the tensional stress. This is certainly the case in the Okinawa Trough.
The northern Okinawa Trough has a very thick (up to 8 $\mathrm{km}$ ) sedimentary cover due to a massive supply from the Yangtze and Yellow rivers. The broad structural pattern is controlled by normal faults, $120-150 \mathrm{~km}$ long and trending $\mathrm{N} 40^{\circ} \mathrm{E}$ to $\mathrm{N} 60^{\circ} \mathrm{E}$ (Figure 2). These fault-bound tilted blocks are generally $10-30 \mathrm{~km}$ wide and define half graben. The presence of Pliocene rocks of the Shimanjiri group in the Toka 1 oil well [Nash, 1979] and in a dredge haul from the 1984 Jean Charcot cruise (latitude $30^{\circ} 04^{\prime} \mathrm{N}$, longitude $128^{\circ} 31^{\prime} \mathrm{E}$ ) suggest that the tilting may have occurred in late Pliocene/early Pleistocene time (Figure 4) and affected the whole sedimentary cover, which probably includes Miocene and perhaps older sediments at its base [Letouzey and Kimura, 1985]. Onlapping Pleistocene sediments up to $2 \mathrm{~km}$ thick partly fill the depressions created during this late Pliocene/early Pleistocene tensional phase. These Pleistocene sediments are, in turn, normally faulted by the present-day phase of extension (Figure 4) as clearly shown in the $3.5-\mathrm{kHz}$ records (Figure 5). Based on the Sea Beam data, which define the strike of the latest faults, their trends differ by about $25^{\circ}$ from the late Pliocene/early Pleistocene stress pattern.

Based on the seismic and Sea Beam data acquired during the POP 1 cruise in the northern Okinawa Trough, and other available seismic data, we have established that the distribution of the numerous late Pliocene/early Pleistocene gra- 


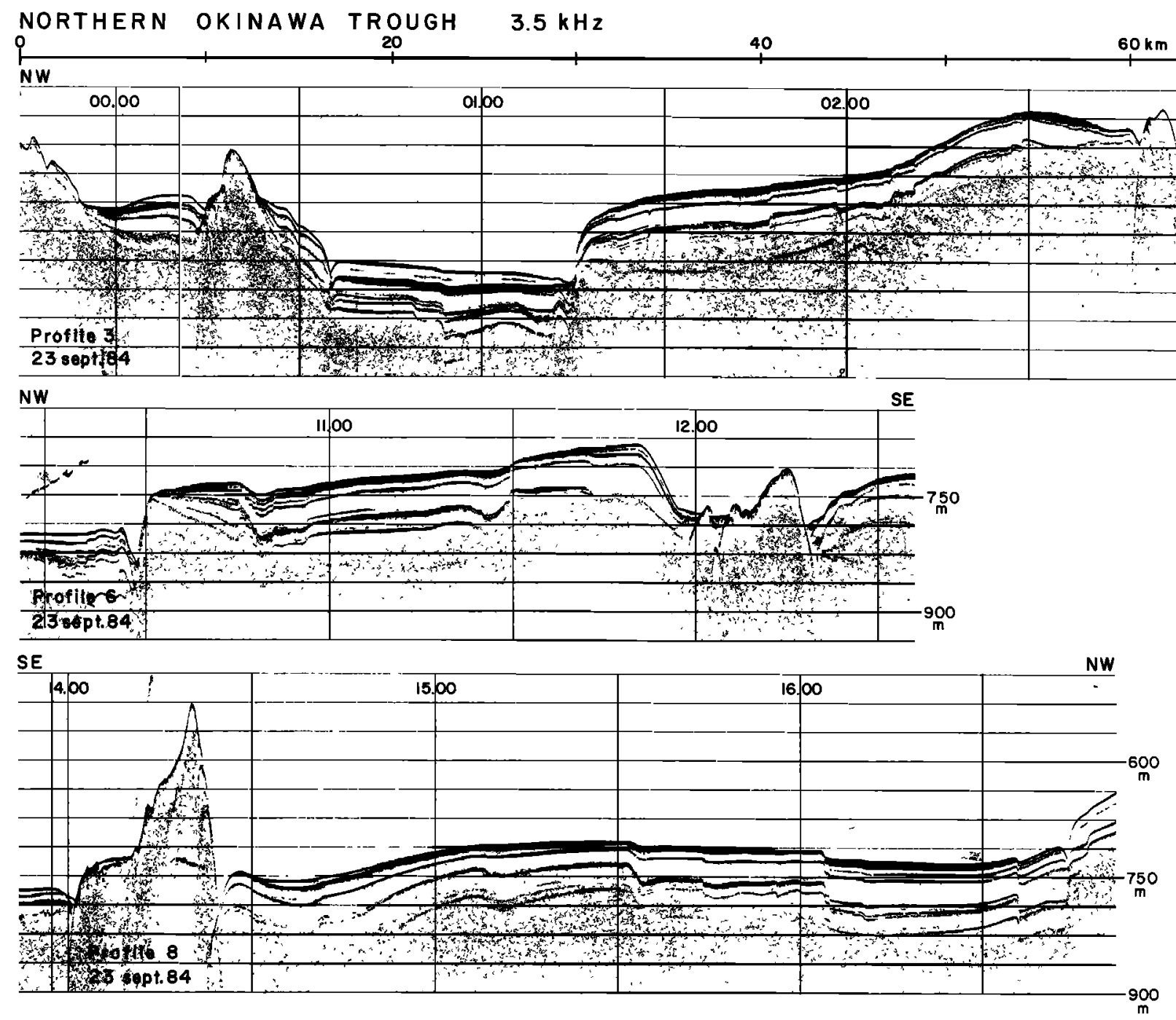

Fig. 5. Examples of 3.5-kHz profiles obtained in the northern Okinawa Trough showing the present-day normal faulting and deformation. Location of profiles 3, 6, and 8 in Figure 3. Vertical exaggeration is about 40.

bens and tilted fault blocks results in a right-lateral en échelon pattern trending roughly $\mathrm{N} 50^{\circ} \mathrm{E}$ (Figure 2). Vertical displacement and associated horizontal extension along the normal fault planes bounding the tilted blocks increase and then decrease along-strike giving the blocks a twisted geometry. No evidence of transform motion between the offset normal faults was observed. This type of extensional tectonics in submarine continental rifts or graben has often been revealed where closely spaced multichannel seismic lines exist [Chenet et al., 1987]. In the absence of transform faults the overall orientation of the basin will depend on the amount of overlap and the distance between normal faults. In other words, the strain pattern is not necessarily normal to the general direction of the basin.

\section{Southern Okinawa Trough}

In contrast to the northern Okinawa Trough, the southern Okinawa Trough west of $127^{\circ} \mathrm{E}$ and southwest of Okinawa Island consists of a broad deep, flat basin, with sediments more than $2 \mathrm{~km}$ thick. Closely spaced, high-amplitude reflectors within the sedimentary sequence suggest dominantly turbidite deposits with a source to the northwest (e.g., Figure 6). Both Hilde et al. [1984] and Kimura [1985] have noticed that sediment accumulation rates were very low during lower
Pleistocene time but very high (up to $4 \mathrm{~km} / \mathrm{m}$.y.) during the last $0.5 \mathrm{~m} . \mathrm{y}$. They attribute this relative lack of deposition during the early history of the deep Okinawa basin to the presence of the Taiwan-Sinzi folded belt, which acted as a structural dam, restricting the Yellow and Yangtze river sediments to deposition within the East China and Yellow Sea basins, which were not yet filled. Hilde et al. [1984] and Vander Zouwen [1985] suggested that the rapid recent deposition within the Okinawa Trough implies that some sediments bypassed the continental shelf basins and may have involved direct discharge of the rivers into the Okinawa Trough during glacial periods.

The late Pleistocene to present-day phase of extension and subsidence is recorded in the whole sedimentary sequence by the downward curvature of sedimentary reflectors toward the center of depressions and by normal faulting and intrusion of volcanic material through the sedimentary column. As an example, profile 147 (Figure 6) displays all of these tensional features. Present-day normal faulting appears in the central portion of the trough between 0110 and 0210 hours (profile 147, Figure 6) and is especially prominent on the simultaneously recorded $3.5-\mathrm{kHz}$ record (Plate 1 and Figures 7 and 8). This faulting is confined to the trough axis and is absent in the remaining part of the basin. The vertical offset along these 

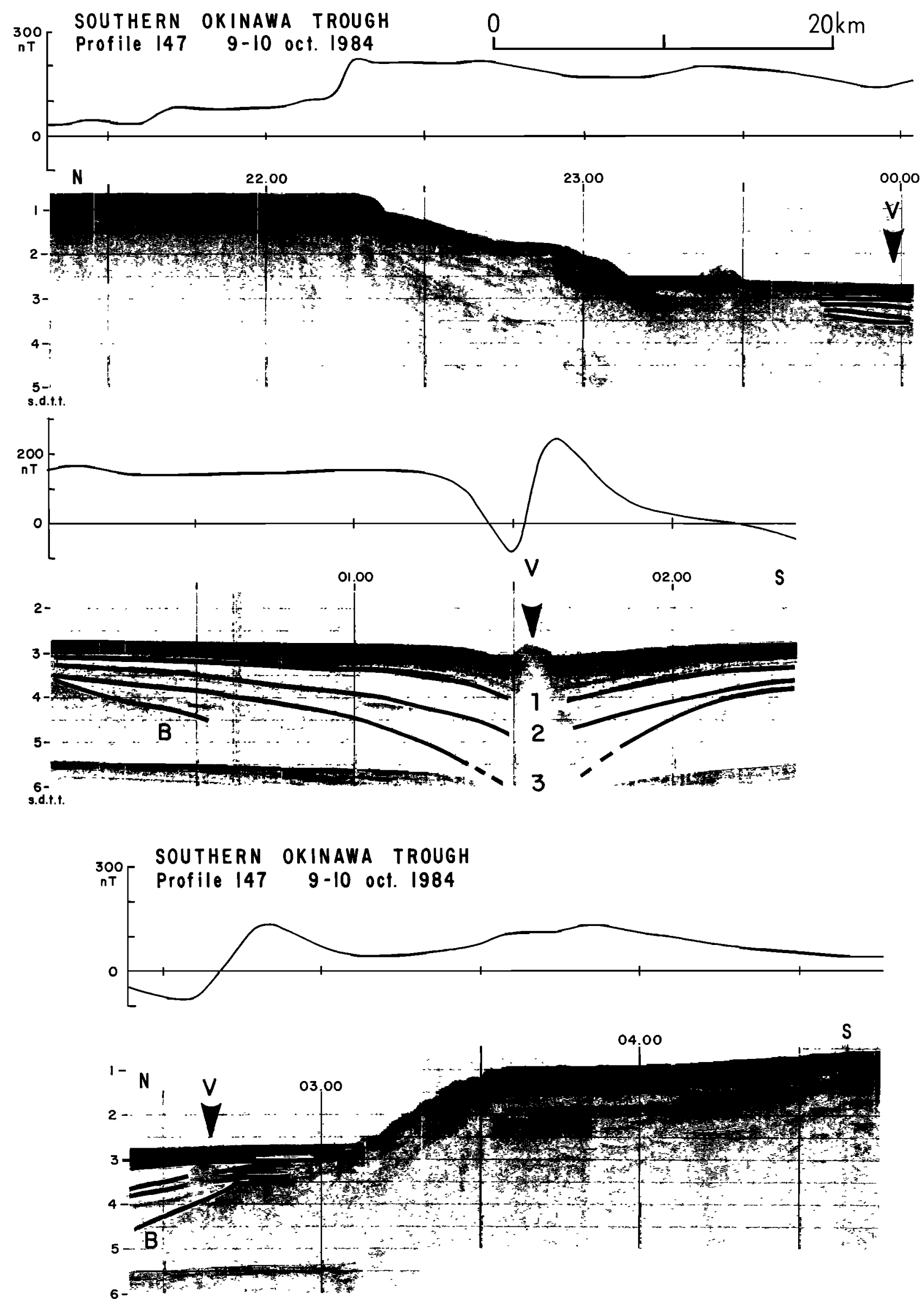

s.d.t.t

Fig. 6. IFREMER, high-speed (10 knots), single-channel seismic profile 147 shot across the southern Okinawa Trough: location shown in Figure 3; vertical exaggeration $\times 3$. Note the downwarping of sedimentary layers, normal faulting, and volcanic intrusions (V) at the center of the trough at 0000 and 0240 hours. Seismic reflectors 1,2 , and 3 and basement (B) are drawn in bold. 


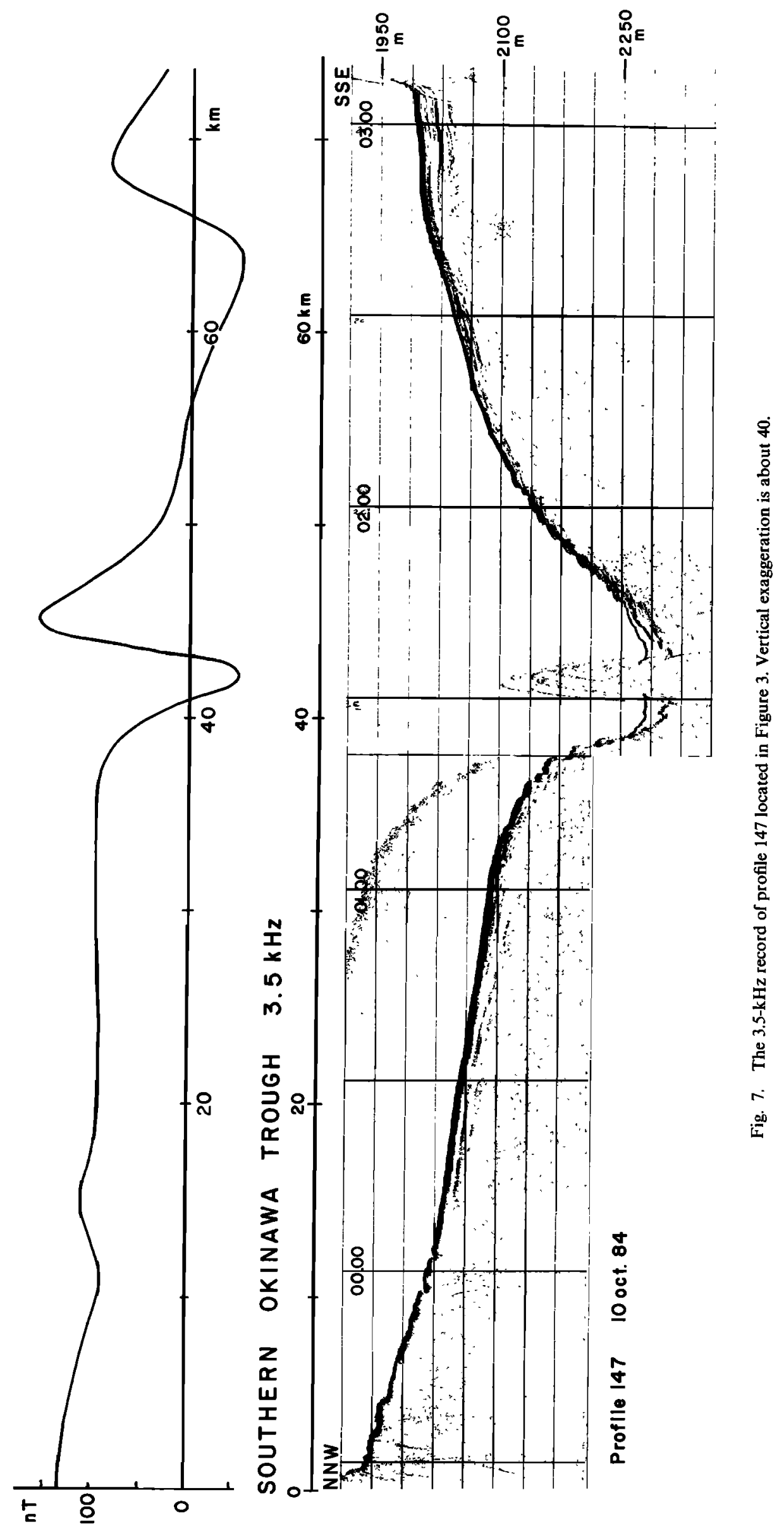




\section{SOUTHERN OKINAWA TROUGH $3.5 \mathrm{kHz}$}
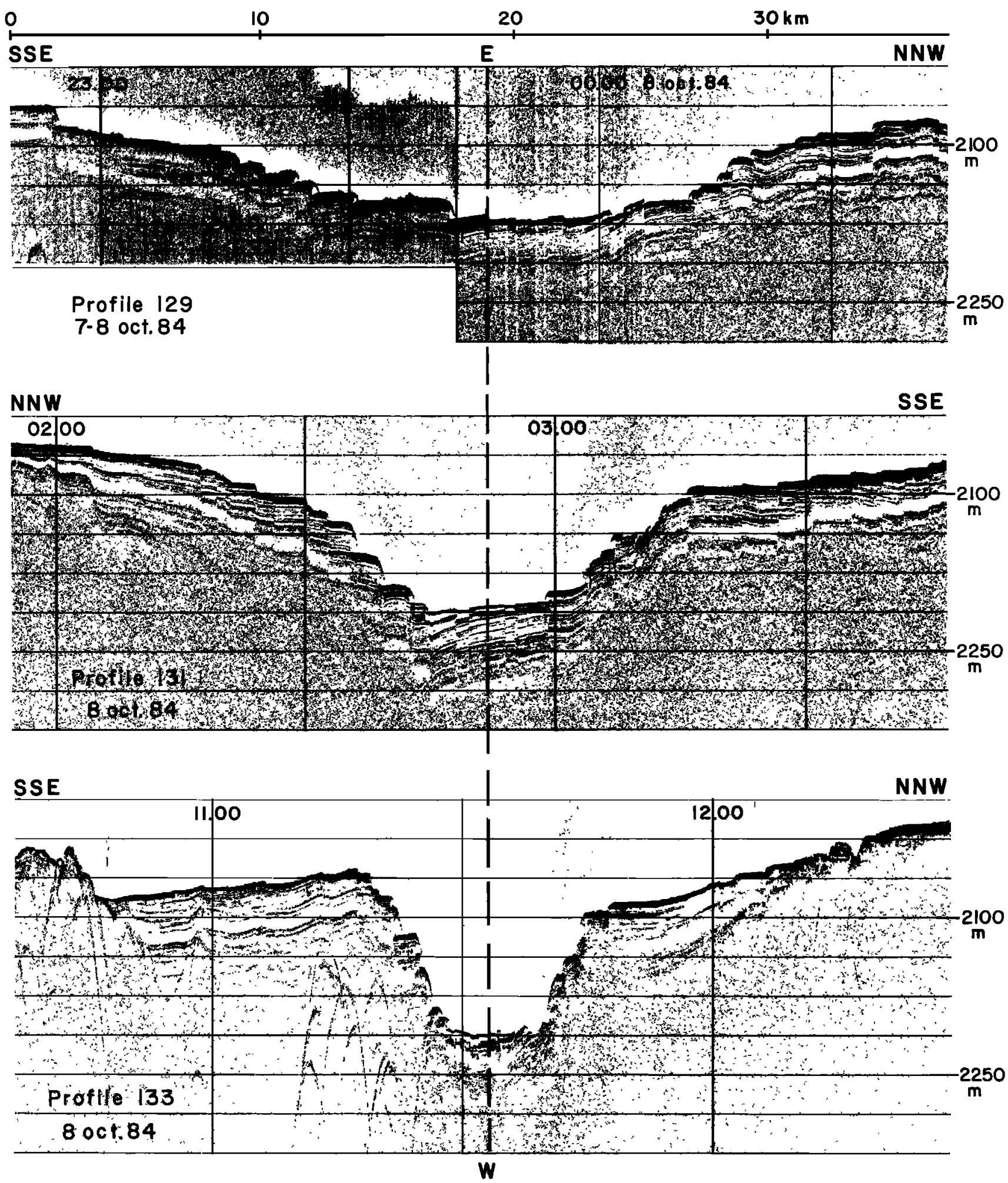

Fig. 8. Normal faulting, subsidence, and intrusion of a basaltic ridge along a depression of the southern Okinawa Trough illustrated on 3.5-kHz records. Profiles 129, 131, 133, 154, 147, 152, and 162 are located in Figure 3. Vertical exaggeration is about 40 . The amplitude of normal faulting varies from a few meters to about $50 \mathrm{~m}$. 

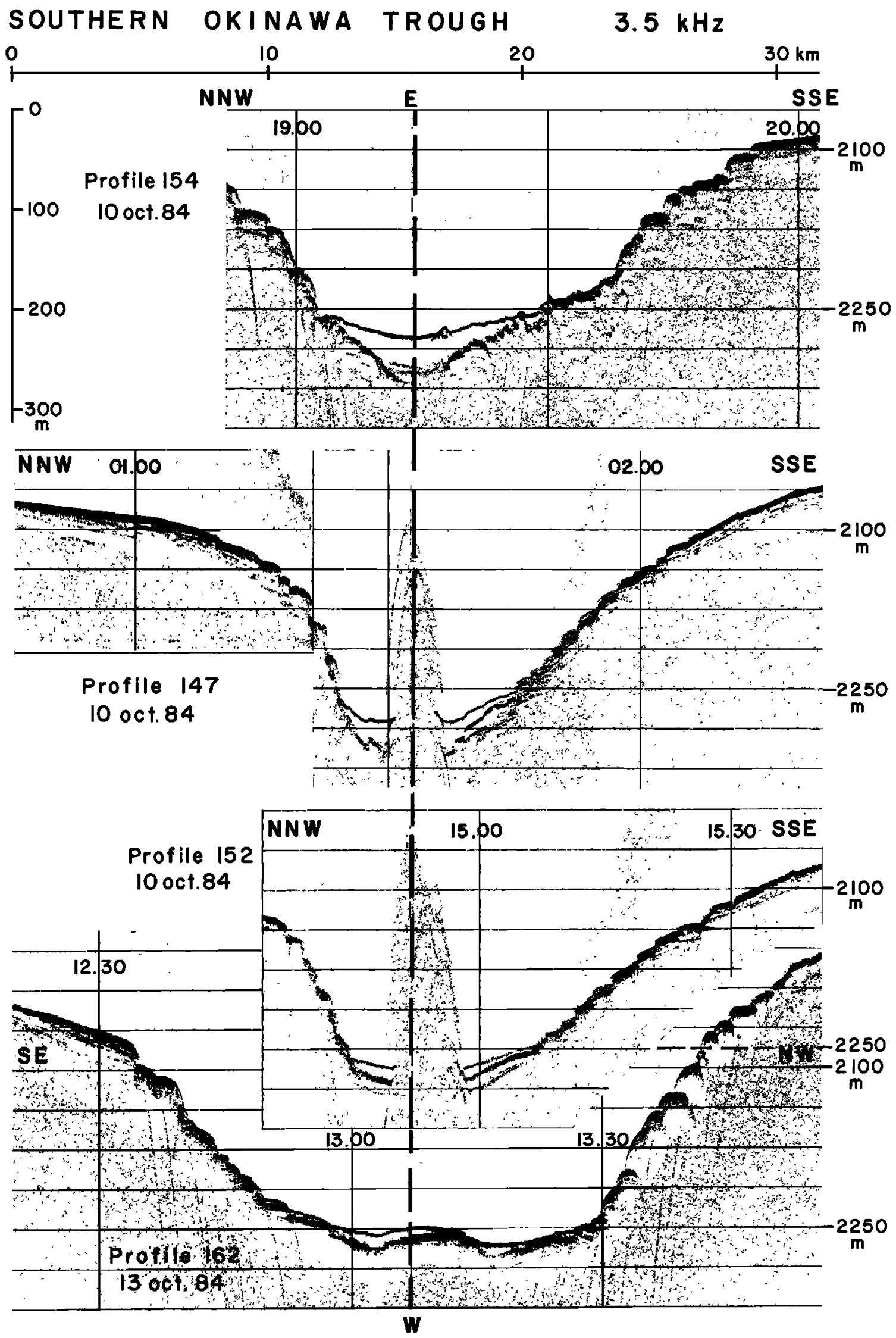

Fig. 8. (continued) 
normal faults varies from a few meters to about $40 \mathrm{~m}$ and is generally greater and consequently steeper on the N-NW side of the central depression. The dip of the normal faults cannot be firmly established because the vertical exaggeration of the $3.5-\mathrm{kHz}$ records is about 40 times. Superficial features (for example, horsts, half grabens, and slumps) at a scale of a few meters to tens of meters are commonly observed. Intruded volcanic ridges associated with large magnetic anomalies appear in the deepest part of the depressions which are the site of maximum extension (Figures 6-8). Fresh vesicular basalt was dredged on one of these volcanic ridges (profile 147, Figures 6 and 7).

On profile 147 , sedimentary layers can be seen to onlap the deep basement on both sides of the trough. The basement disappears on both sides of the central depression at a distance of $15 \mathrm{~km}$. Thus except for these central $30 \mathrm{~km}$, basalt sediments are older toward the axis, which excludes seafloor spreading as a mechanism, as proposed by Kimura [1985], to explain the origin of the region outside the central depression. Furthermore, we suggest an alternative interpretation of a multichannel seismic (MCS) profile [Kimura, 1985, Figure 15] which limits the width of back arc basin oceanic crust in the center of the southern Okinawa Trough to less than $40 \mathrm{~km}$ as opposed to the more than $80 \mathrm{~km}$ in Kimura's interpretation. Kimura [1985] interpreted the MCS profile as showing a deep horizontal reflector intersecting the base of an axial-dipping sedimentary sequence. In that case, sediments in contact with this deep reflector are younger toward the axis. This argument was used by Kimura [1985] to infer that seafloor spreading was the mechanism of formation of the southern Okinawa Trough. A careful examination of this MCS profile shows that basement of probable continental origin extends to within less than $20 \mathrm{~km}$ of the axis and that sediments above this basement are older toward the axis. This observation restricts the domain of oceanic crust to at most $40 \mathrm{~km}$.

Another argument against a wide oceanic area comes from the morphology of the basement which dips toward the axial depression at the base of the margin. The basement morphology is either flat or displays horst-and-graben structures which closely resemble the tilted fault block geometry observed on passive continental margins such as the northern Bay of Biscay [e.g., Montadert et al., 1979; Le Pichon and Sibuet, 1981]. On profile 131 (Figure 9), this type of basement, which could be associated with thinned continental crust, disappears at a distance of less than $15 \mathrm{~km}$ from the axis of the central depression.

Complementary observations reinforce the view that a limited amount of oceanic crust exists in the southern and middle Okinawa Trough: intrusions at 0000 and 0240 hours on profile 147 (Figures 6 and 7) are associated with normal polarity magnetic anomalies. Magnetic and seismic data acquired along nearby profiles indicate that these intrusions extend in an east-west direction. Assuming that sedimentation in the trough is mainly of turbidite origin, sedimentary layers were nearly horizontal at the time of deposition. The general bending of seismic reflectors within the sedimentary sequence toward the axis suggests an increasing subsidence and tilting of the crust toward the axis. A main phase of tilting affects horizon 2 which is overlain by a major onlapping sequence (Figure 6). Breaks in the dip of acoustic reflector 2 occur at 0000 and 0240 hours and correspond to the previously described E-W dyke intrusions. This observation suggests that the elongated dyke intrusions associated with low-magnitude magnetic anomalies observed outside the central depression of the southern Okinawa Trough are linked to the rifting rather than to the spreading phase of back arc basin opening.

We can make a rough estimate of the tectonic subsidence on profile 147 for the center of the depression (0130 hours) with respect to the present-day seafloor depth at the edge of the basin (2345 hours). Assuming a $2 \mathrm{~km} / \mathrm{s}$ velocity in the sediment and a regional isostatic readjustment equal to half the mean sedimentary thickness, the tectonic subsidence obtained by substracting the effect of the sedimentary load is $0.29,0.70,1.06$, and $1.48 \mathrm{~km}$ for the sea bottom and reflectors 1,2 , and 3 , respectively (Figure 6). The tectonic subsidence increases with age and in direction of the axis of the back arc basin. As the age of reflector 3 is less than $1 \mathrm{~m} . y$., the expected tectonic subsidence of a zero-age oceanic crust (in that case the thermal subsidence) would be about $150 \mathrm{~m}$, that is, 1 order of magnitude lower than the observed tectonic subsidence. But the amplitude of the tectonic subsidence is compatible with the initial subsidence of a continental crust thinned by uniform stretching for example. Consequently, the southern Okinawa Trough is probably composed of continental crust thinned by tensional processes, and not of oceanic crust.

All these observations suggest that most of the southern Okinawa Trough is a subsiding continental basin with extension increasing toward the axis. If oceanic crust created during late Pleistocene time exists in the basin, it must be restricted to a very narrow band less than $40 \mathrm{~km}$ wide. In the extreme case, back arc basin oceanic crust may be reflected only by the late Pleistocene to present-day basaltic intrusions observed at the axis of the central depressions. In that case, the fundamental difficulties in Kimura's model, associated with a water depth decreasing as a function of age and an unconvincing interpretation of the low-magnitude magnetic lineations due to seafloor spreading reversals, are removed. Moreover, the duration of the rifting phase in the southern Okinawa Trough could reach at least 1-1.5 m.y. instead of less than a hundred thousands years as in Kimura's interpretation.

The spatial distribution of depressions in the southern Okinawa Trough displays an en échelon pattern characterized by a partial overlapping of these tensional features (Figure 2). As in the northern part of the trough, the subsidence increases along the axis of the depressions, reaching a maximum value and then decreases. In the extreme case, when subsidence and extension are at a maximum, volcanic ridges up to $300 \mathrm{~m}$ high and several tens of kilometers long are emplaced along the axis of the depression. During the POP 1 cruise, basalt was dredged several times along these volcanic units. Preliminary chemical analyses indicate a strong "subduction-related" fingerprint. In particular, the trace element patterns and isotopic compositions fall within the observed range for island arc series [Sibuet et al., 1986]. As previously noted by Lee et al. [1980] and Kimura [1985], the high-amplitude magnetic anomalies are restricted to these elongated volcanic features.

A major point illustrated by the POP 1 seismic data and previously acquired seismic lines is that there is no evidence of transform motion between the en échelon central depressions. This was recently suggested by Letouzey and Kimura [1985] but is in opposition to ideas developed by Lee et al. [1980] and Vander Zouwen [1985], who inferred N-S offsets of the axial depressions and interpreted these as right-lateral transform faults between spreading ridge segments. The observed tensional pattern (Figure 2) may be related to a very primitive, non-steady state stage of seafloor spreading. A similar pattern 


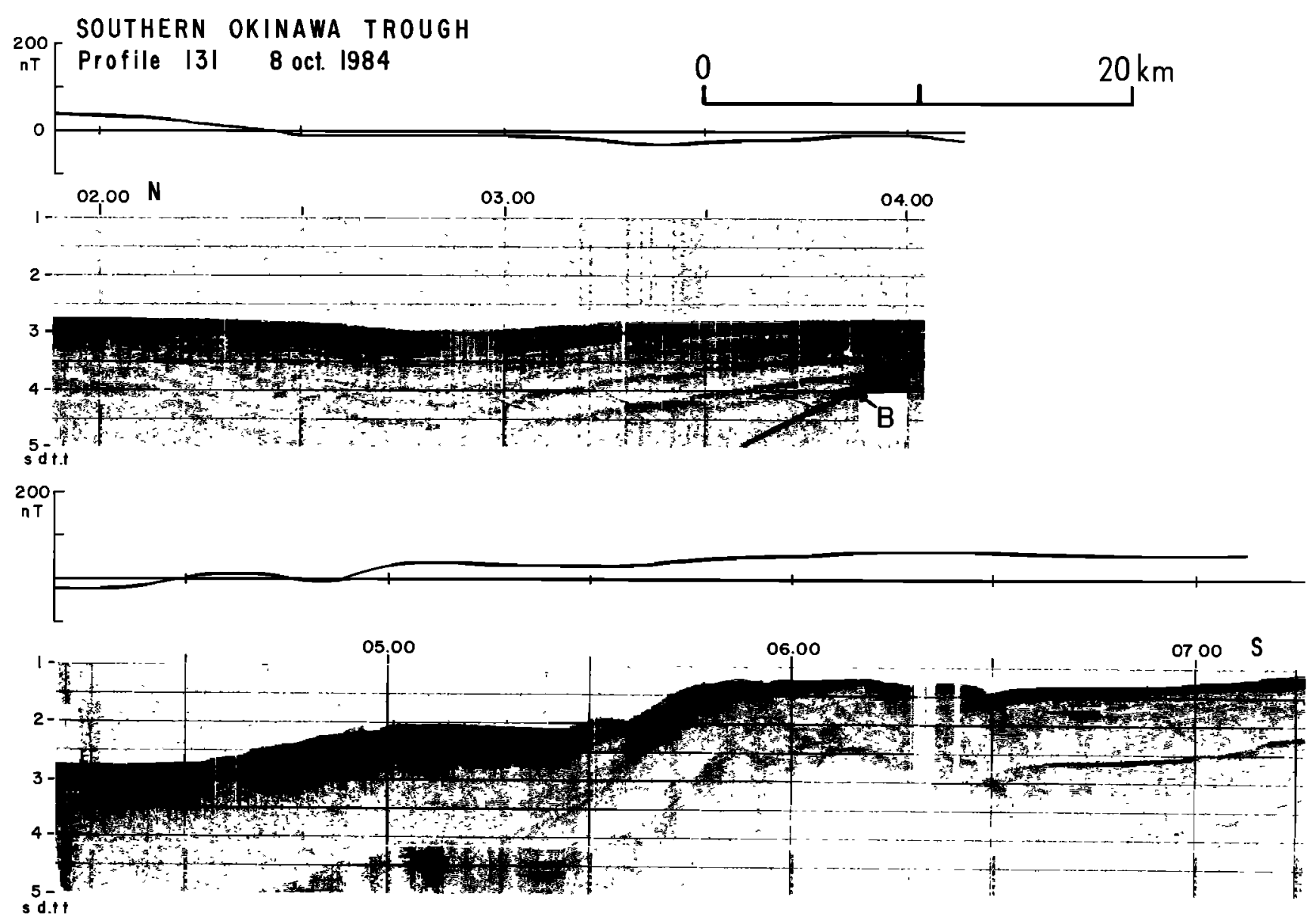

Fig. 9. IFREMER, high-speed (10 knots), single-channel seismic profile 131 and magnetic anomaly profile located in Figure 3 showing that possible continental basement (B) could extend as far as the axis of the depression. Continental basement is underlined. Vertical exaggeration $\times 3$.

of extension with no transform motion was recently observed in the Gulf of Tadjourah at the westernmost end of the Gulf of Aden. Observations there from the submersible Cyana showed that there is no surface evidence for any transform faults and that the incipient spreading segments do not define a plate boundary [Cyaden Scientific Team, 1986].

\section{Middle Okinawa Trough}

The middle Okinawa Trough is a transitional area between the northern trough with a thinned continental crust and the southern trough characterized by a present-day system of en échelon depressions with elongated basaltic ridges that are interpreted as exposed back arc basin oceanic crust. The transitional area, located at latitude $27.5^{\circ} \mathrm{N}$, longitude $127^{\circ} \mathrm{E}$, about $100 \mathrm{~km}$ northwest of Okinawa Island, and which has been named the volcanic arc rift migration phenomenon (VAMP) area represents the transition between the thinned continental crust and the first sign of back arc basin oceanic crust and also the transition from present-day arc volcanism to volcanism associated with back arc spreading centers.

Sea Beam mapping of the VAMP area allowed us to produce a precise bathymetric map (Figure 10) with a Sea Beam coverage of about $40 \%$. The map shows a series of parallel ridges (Figures 10 and 11 ) elongated in the $\mathrm{N} 70^{\circ} \mathrm{E}$ direction and culminating at a water depth of about $1000 \mathrm{~m}$, about 600 $\mathrm{m}$ shallower than the flat basin floor. Fresh basalt was recovered at latitude $27^{\circ} 34.4^{\prime} \mathrm{N}$, longitude $127^{\circ} \mathrm{E}$ during the POP 1 cruise. In the eastern part of the VAMP area during a dive of the Japanese submersible "Shinkai 2000" [Uyeda et al., $1985 b$ ], andesite and dacite rocks were collected. Analyses made in Japan show that rocks collected are island arc type in major element chemistry and preliminary trace element and isotopic analyses of the POP 1 rock samples confirm this island arc type identity [Sibuet et al., 1986].

Seismic profile 53 (Figure 12) was shot perpendicular to the ridge system and gives evidence for regional extension across the VAMP area. The greatest depth is observed in the central part of the VAMP area, suggesting that the volcanic ridges are emplaced in the axial portion of a continental basin. This depression about $50 \mathrm{~km}$ wide is $200 \mathrm{~m}$ deeper than the adjacent area (Figures 10 and 12). The sedimentary sequence, more than $1 \mathrm{~km}$ thick as seen on POP 1 cruise seismic profiles and $2 \mathrm{~km}$ thick on evidence from the Japanese ocean bottom seismometers (OBS) experiment [Uyeda et al., 1985a; Nagumo et al., 1986], is cut by present-day normal faulting, giving rise to a large depression and associated volcanic intrusions.

Projected magnetic anomalies along the track lines of the VAMP survey show that the volcanic ridges are associated with magnetic anomalies of the same polarity (Figure 13). Davagnier et al. [1987] have modeled magnetic anomalies in terms of a system of dyke intrusions through the thinned continental crust and seafloor spreading-type anomalies. In the first case, they suppose that the remanent magnetic vector has the same direction as the present-day magnetic field and that volcanic rocks are not older than a few hundred thousands years. The measured intensity of magnetization of the POP 1 


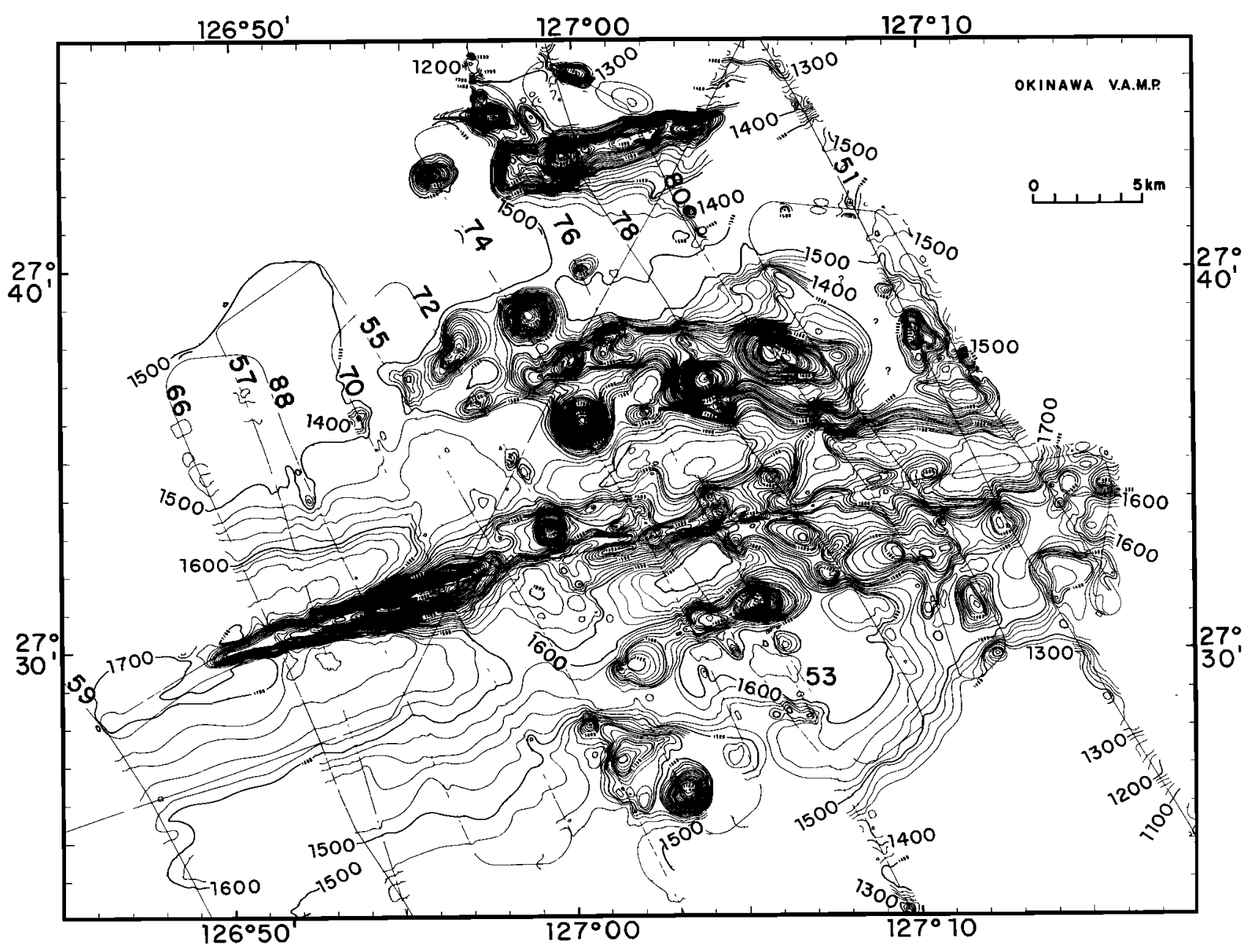

Fig. 10. Bathymetric map of the VAMP area (see Figure 3 for location). Sea Beam coverage is aboul $40 \%$. Track line control shown by continuous thin lines. Contour interval is $20 \mathrm{~m}$. Water velocity is $1500 \mathrm{~m} / \mathrm{s}$.

dredge DR02 samples (Figure 13) has an average value of 1.7 $\mathrm{A} / \mathrm{m}$. As the temperature gradient is about $100^{\circ} \mathrm{C} / \mathrm{km}$ [Yamano et al., 1987], the base of magnetic sources which corresponds to the Curie isotherm has been taken to be $5 \mathbf{~ k m}$. A two-dimensional model has been computed for profile 53 located in Figure 13. Synthetic and observed anomalies are in good agreement (Figure 14) which suggests that the magnetic anomalies of the VAMP area are consistent with a series of linear dyke intrusions through the continental crust. Nevertheless, the existence of magnetic lineations trending $N 75^{\circ} \mathrm{E}$ can be also correlated with the geomagnetic reversal time scale. If we suppose that accretion began 2 m.y. ago, stopped $0.5 \mathrm{~m} . y$. ago, and started again recently [Kimura, 1985], the Olduvai (1.87 m.y.) and Jamarillo (0.97 m.y.) events can be identified (Figure 15). A good correspondence exists between observed and computed anomalies for the profile 53 with a half spreading rate of $2 \mathrm{~cm} / \mathrm{yr}$. These results are similar to those of Kimura et al. [1985], but the number of cycles of magnetic anomalies in the VAMP area is too small to give confidence in the correlations with the geomagnetic time scale. A model in which the half spreading rate is $4 \mathrm{~cm} / \mathrm{yr}$ (Figure 15 ) is also valid. Consequently, magnetic data cannot be used to discriminate between intrusion and the seafloor spreadingtype models, and the cessation of rifting during the Pleistocene as proposed by Kimura [1985] could not exist.

We note that just southwest of the VAMP area, the crustal structure consists of sediments overlying a 5-km-thick, 6.0 $\mathrm{km} / \mathrm{s}$ upper crustal layer and a $6.8 \mathrm{~km} / \mathrm{s}$ layer which probably corresponds to the lower crust [Uyeda et al., 1985a; Nagumo et al., 1986]. The acoustic velocity distribution of the crust in the middle and southern Okinawa Trough is very similar, except for the absence of the $4.6-5.2 \mathrm{~km} / \mathrm{s}$ layer in the middle Okinawa Trough. Uyeda et al. [1985a] and Nagumo et al. [1986] suggest that the $6.0 \mathrm{~km} / \mathrm{s}$ velocity is characteristic of a granitic layer. If this assumption is correct, then it provides an argument for the presence of thinned continental crust everywhere in the Okinawa Trough except in the areas of volcanic intrusions, in the axial depressions, and in the VAMP area. Thus the approximately 50-km-wide depression of the VAMP area, which is oriented $N 75^{\circ} \mathrm{E}$, can be interpreted as a subsiding continental basin largely affected by back arc volcanism. Furthermore, we note that transform faults do not exist on the northeastern and southwestern sides of the VAMP area which is an argument against the presence of oceanic crust there and in favor rather of thinned continental crust intruded by volcanics.

\section{Discussion and Conclusions}

The scheme of the Okinawa platelet as deduced from POP 1 data is shown in Figure 16. This platelet is bounded on the eastern side by the Ryukyu trench, on the western side by eastern Taiwan, and on the northwestside by the axial rift pattern of the southern Okinawa Trough and the VAMP area. The northern Okinawa Trough may or may not be the north- 


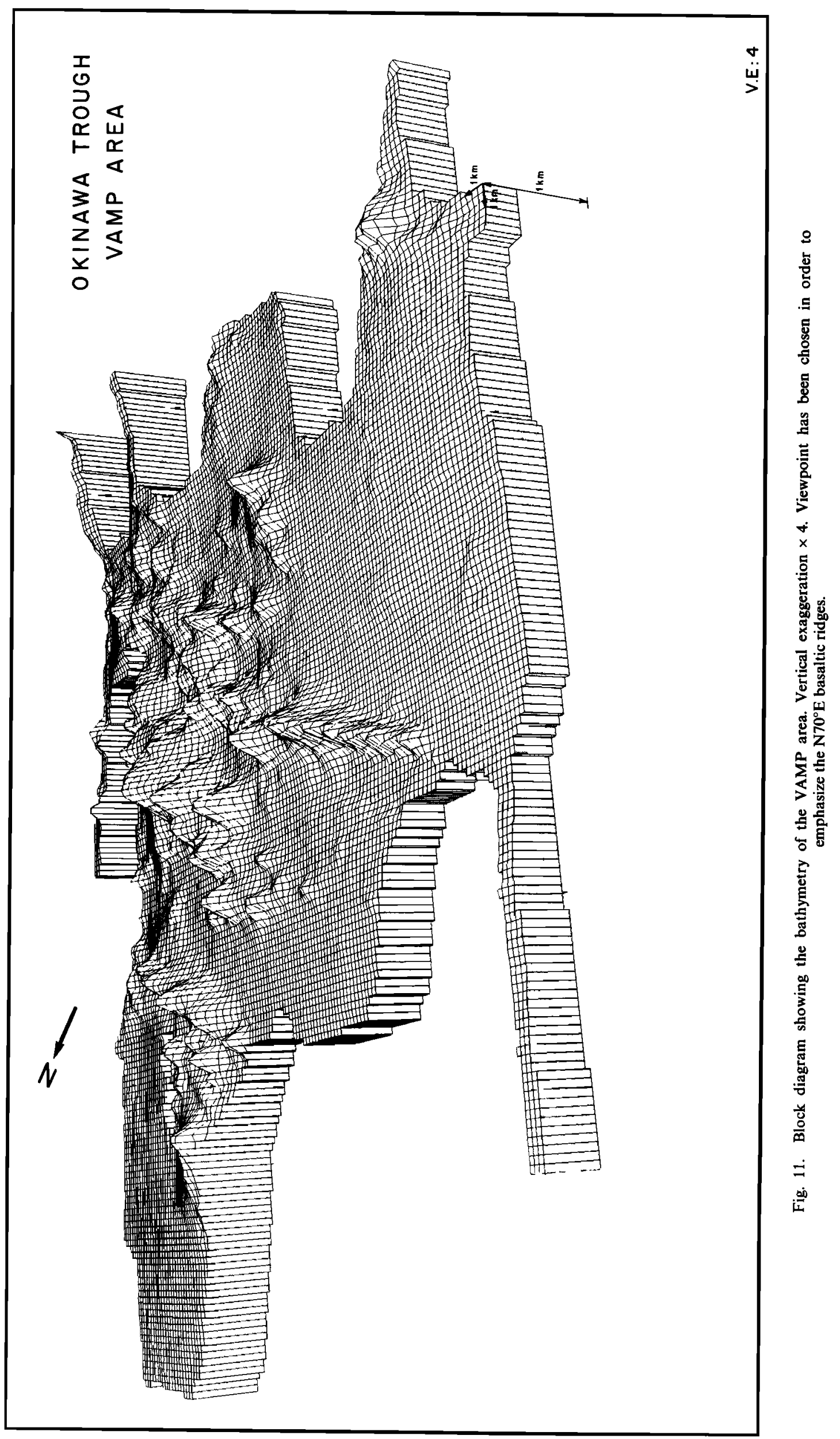




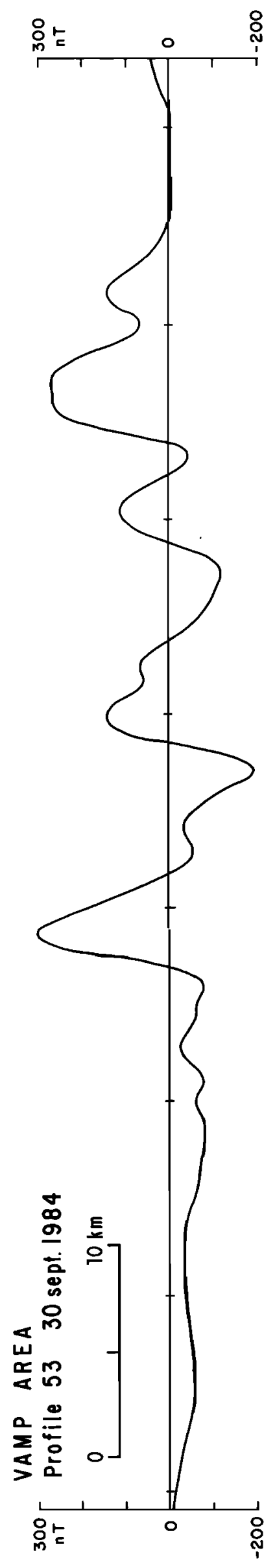

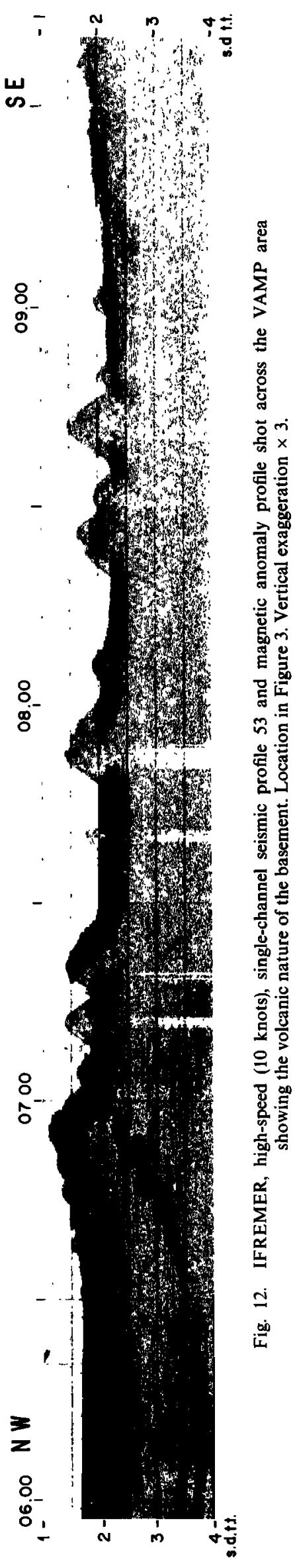

ward continuation of this boundary. Assuming it is, even though only extension is observed, the width of the extensional zone increases to the northeast. The entire active volcanic arc is included in the Okinawa platelet. The Okinawa platelet is limited by the Philippine sea plate at a maximum depth of $200 \mathrm{~km}$.

Active extension behind island arcs is related to processes of subduction of the oceanic lithosphere along the margins of converging plates. Karig [1971] first attributed the formation of Pacific marginal basins to back arc spreading. Proposed models for the tensional origin and spreading mechanism of back arc basins range from frictional heating models [Minear and Toksöz, 1970; Hasebe et al., 1970; Uyeda, 1977, 1984], which imply massive vertical transfer of heat through extensive magmatism or dispirism from the downgoing slab, to secondary flow models forced by the descending slab and giving rise to a convection cell which is able to transfer heat upward [Sleep and Toksöz, 1971; Andrews and Sleep, 1974; Toksöz and Bird, 1977; Jurdy and Stefanick, 1983]. Chase [1978] and Uyeda and Kanamori [1979] showed that most of the major plates lying behind the trenches move away from the subduction zones in a hot spot reference frame (retreat model). This observation suggests that the marginal basin opening may be related to a component of "trench suction" in the driving forces of plate tectonics. Using a two-dimensional finite element model with an elastico-plastic behavior, Viallon et al. [1986] show that the opening of the Okinawa Trough can be explained by a retreating trench model with lateral anchorings due to the collision in Taiwan and buoyant subduction of the Palau-Kyushu ridge. It results in the arcuate shape of the Ryukyu arc and trench. The dyssymetry in shape and width of the Okinawa Trough could be explained by lateral variation of the suction force related to the variation of the length of the subducting slab.

Molnar and Atwater [1978] demonstrated that subduction of ocean floor older than 50 m.y., and especially older than $100 \mathrm{~m} . y$., is commonly associated with interarc spreading. In that case, heavy, old oceanic lithosphere may be pulled down more rapidly than the plates can converge (roll back model), which could explain extensional processes beginning at the volcanic arc where a preexisting zone of weakness exists. Coupling between the downgoing slab and the lithosphere of the arc at the subduction boundary induces a transfer of a component of horizontal push to the lithosphere of the arc. Froidevaux et al. [1987] suggest that the interplate push seems to vary from more than 660 bars for the Chilean-type to less than 100 bars for the Mariana-type subduction boundary. The Ryukyu subduction zone belongs to the second system. In that case, the Froidevaux et al. [1987] modeling suggests that back arc basins originate by splitting of the volcanic arc, as previously proposed by Molnar and Atwater [1978]. This is not the case for the Okinawa Trough. For the first time, we have clearly demonstrated that extension there is mostly expressed as, and restricted to, a system of linear intrusions or to their graben and to normal fault prolongations trending obliquely to the arc.

In contrast with the elongated volcanic features of the back arc basin, the volcanoes of the arc itself present an irregular shape. The size decreases considerably from Kyushu Island to the latitude of the VAMP area where the last active volcano is only a few kilometers in diameter. As previously noted by Letouzey and Kimura [1985] the volcanic centers of the arc 


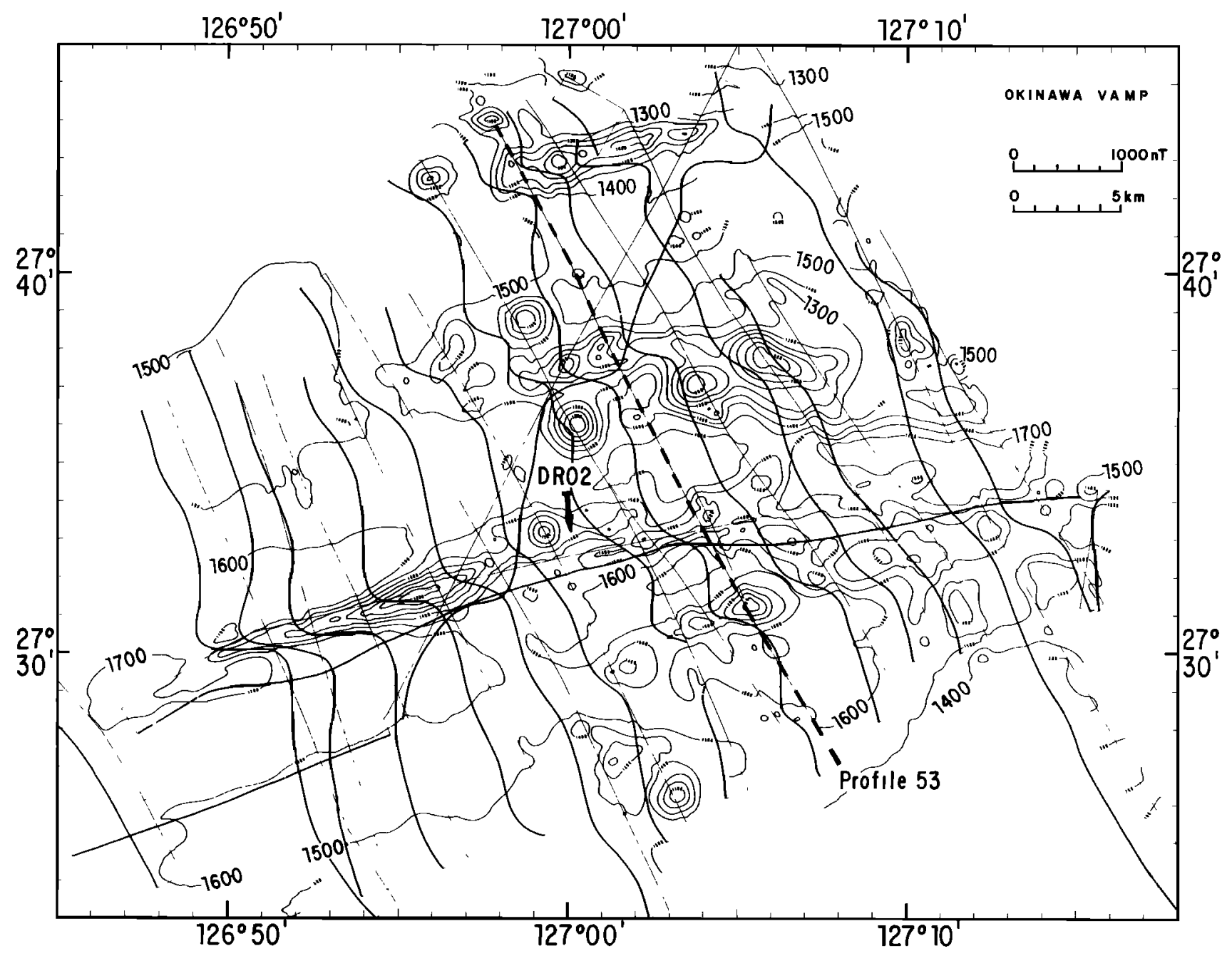

Fig. 13. Magnetic anomalies projected perpendicularly to the track lines in the VAMP area. Simplified bathymetry of Figure 10 with a $100-\mathrm{m}$ contour interval.

are aligned above the 80 - to $120-\mathrm{km}$-deep Wadati-Benioff zone at a distance of $160-250 \mathrm{~km}$ from the trench (Figure 16). However, there is no active arc volcanism between the VAMP area and Taiwan except one unconfirmed historical submarine eruption reported in the vicinity of Yaeyama islands ( $M$. Kimura, personal communication, 1985). It is only just north of Taiwan that the Taiwan-Sinzi folded belt is intruded by recent calc-alkaline volcanism that might be related to the Ryukyu arc volcanism [Letouzey and Kimura, 1985].

Consequently, along the Ryukyu subduction zone there is an alternation between arc volcanism and back arc spreading activity, as previously remarked on by Honza [1983]. The arc volcanism is characterized by a decrease in activity toward the southwest and terminates near the transitional VAMP area. Only back arc volcanism exists southward of this area. The depth of the Wadati-Benioff zone under the site of volcanic activity [Eguchi and Uyeda, 1983] increases from $80-120 \mathrm{~km}$ below the volcanic arc to $100-175 \mathrm{~km}$ below the back arc basin (Figure 16). The difference in morphology between the arc volcanism, characterized by irregular forms, and back arc volcanism, emplaced as elongated ridges, might result from this slight difference in depth to the subducting slab. In the Ryukyu subduction system, back arc volcanism, arc volcanism, and normal faulting in the thinned northern Okinawa continental crust can be considered as alternative responses to tensional stresses in this convergent system.

As shown by the comparison of the character and thickness of crust in the northern and southern Okinawa Trough, back arc volcanic activity is observed only after considerable thinning of the continental crust has taken place behind the island arc, while arc volcanism occurs simultaneously with earlier back arc basin rifting phases or even with a comparatively small amount of extension. We thus suggest that initial injection of back arc basin oceanic crust in the Okinawa Trough is globally migrating to the northeast as the critical amount of crustal extension is exceeded. The direction and amplitude of the motion of the Philippine sea plate with respect to Eurasia are nearly constant along the Ryukyu trench. The northeastward migration of back arc basin volcanic activity is therefore mainly controlled by the width of the Okinawa Trough, which increases by a factor of 2 toward the northeast. Assuming that the total extension needed to create oceanic back arc basin crust is everywhere the same behind the Okinawa Trough arc, spreading should have initiated in the south and propagated northeastward, as the new data show.

Molnar and Atwater [1978] and more recently Froidevaux et al. [1987] have pointed out that "the volcanic arc is a fundamental line of weakness within the lithosphere and as 


$$
\text { - Profile } 53-
$$

\section{NW}
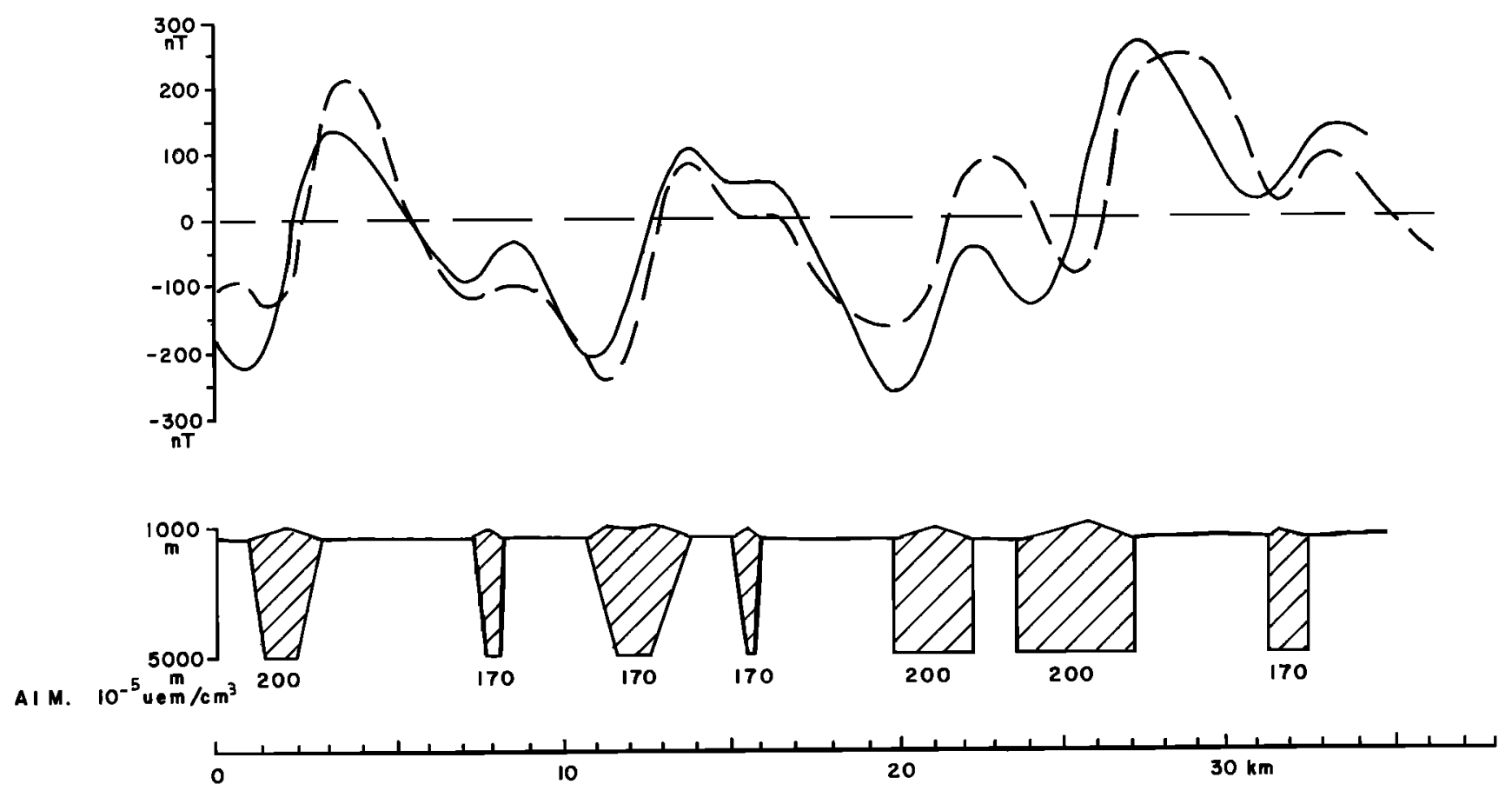

Fig. 14. Comparison of observed and synthetic magnetic anomalies for profile 53 located in Figure 13: dyke intrusion model. Dashed curve, observed; solid curve, synthetic.

such controls the place where spreading begins." For example, the Tonga arc split along an older volcanic arc to form the inactive Lau Ridge and the active, present-day arc. In their opinion, the volcanic arc is a line of weakness where spreading may initiate. But in the Okinawa Trough, directions of the ridges in the VAMP area make a significant angle (about $35^{\circ}$ ) with the direction of the volcanic line of the arc (Figure 2). The northeastern part of the VAMP area is about $50 \mathrm{~km}$ away from the last active volcano of the chain. This volcano lies along the extension of the $N 75^{\circ} \mathrm{E}$ trends of the VAMP area. We thus suggest that locally the oceanic domain of the back arc basin starts in the vicinity of the southernmost volcano and propagates in the $\mathrm{N} 285^{\circ}$ direction but globally that spreading propagates northeastward as previously seen. In the future, we expect that the VAMP area will migrate northward, starting in the $\mathrm{N} 285^{\circ}$ direction from the new location of the abandoned end of the volcanic chain. In that case, the chain could be considered as the starting line of each $N 285^{\circ}$ new VAMP area and not rigorously as the line of weakness along which spreading occurs. In the Okinawa Trough this mechanism cannot produce a splitting of the volcanic arc either for the present-day or for the Miocene arc, which was affected by the late Pliocene/early Pleistocene rifting phase, because the early Pleistocene directions of rifting are also oblique with respect to the orientation of the Miocene arc. Due to this obliquity, splitting of the Miocene volcanic arc has probably never occurred. If the rift directions would have been parallel to the volcanic line, the trough would probably have developed by splitting of the arc with emplacement of oceanic crust, as observed in the Lau [Watts et al., 1976; Weissel, 1977] or Mariana [Bibee et al., 1980] back arc basins, for example.

The more accurate relative motion through time of the Philippine sea plate with respect to Eurasia has been established by Seno [1977] and Seno and Maruyama [1984]. Because this relative motion is, in general, oblique to the arcuate shape of the Ryukyu trench, we suggest that this obliquity is at the origin of the angle between the strike of the graben and the strike of the trench, as well as the cause of the en échelon pattern developed within the back arc basin. Most of the models of back arc processes imply that back arc extension is perpendicular to the trench axis. If we add to this extension an oblique component due to the oblique resisting force applied to the edge of the overriding plate, the extensional stress regime in the back arc basin will have the minimum principal stress $\sigma_{3}$ oblique to the trench axis and to the weak volcanic arc zone. Thus we could expect the development of en échelon graben perpendicular to $\sigma_{3}$ within and behind the arc. The Ryukyu platelet will have an extensional strike-slip movement, with a southward component of the motion with respect to Eurasia (Figure 17). Oblique extension with an en échelon normal fault pattern has also been described in the Suez Rift area [e.g., Chenet et al., 1987]. Furthermore, this process could be involved in the oblique opening of the Andaman Sea back arc basin.

The formation of the Okinawa back arc basin results from several distinct tectonic phases occurring in a short period of time. As the back arc basin evolution is closely related to the convergence process, it seems that each slight change in the 


\section{- Profile $53-$}
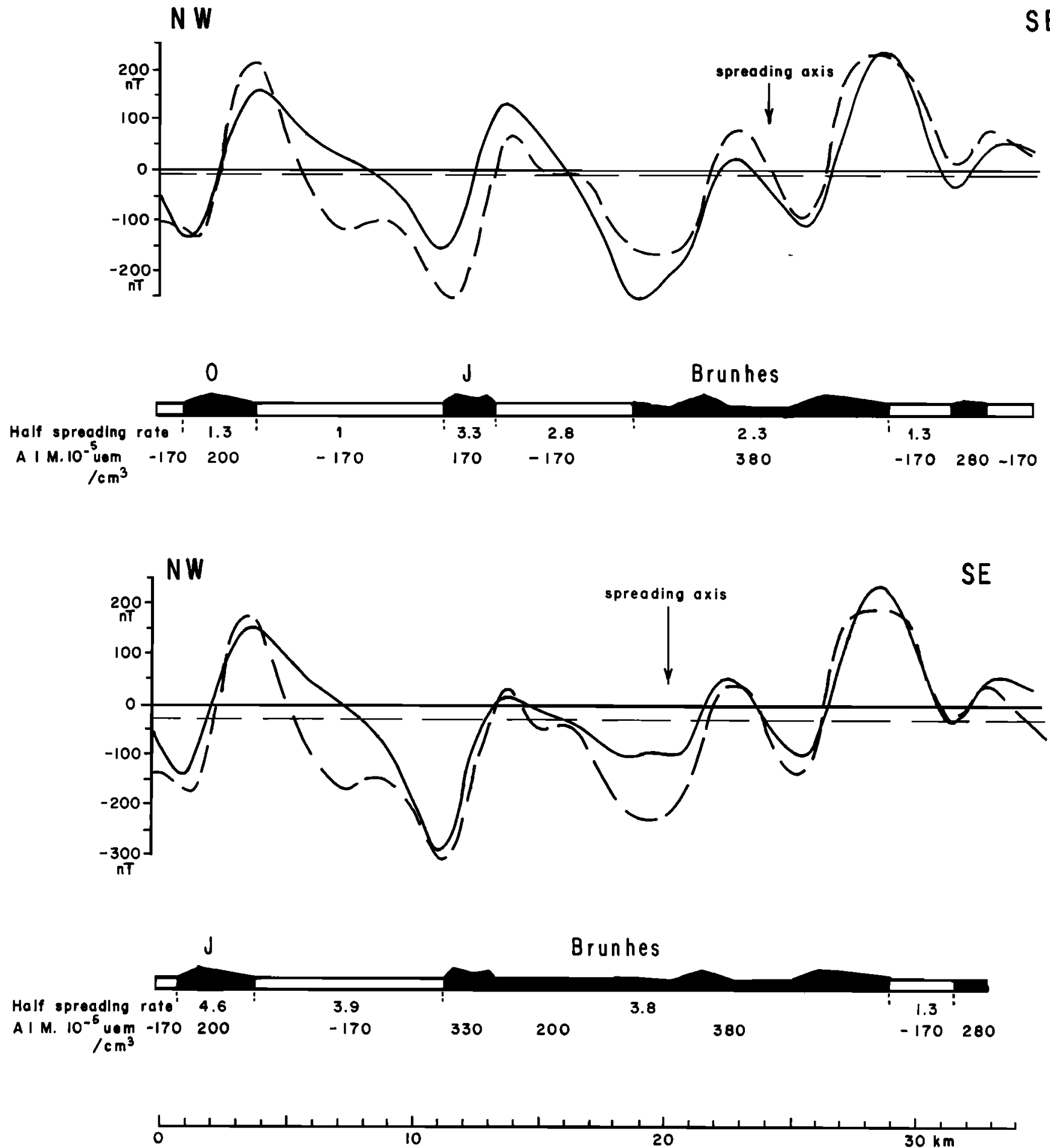

Fig. 15. Comparison of observed and synthetic magnetic anomalies for profile 53 located in Figure 13. Two types of correlations between observed and the geomagnetic time scale inversion anomalies are proposed (top, half spreading rate of $2 \mathrm{~cm} / \mathrm{yr}$; bottom, hall spreading rate of $4 \mathrm{~cm} / \mathrm{yr}$ ). Dashed curve, observed; solid curve, synthetic.

subduction regime (convergence rate, angle of convergence, angle of the Wadati-Benioff zone) would produce a major tectonic change in the evolution of the back arc basin. As the plate kinematic analyses are not precise enough to detect such changes in the convergence rate or in the angle of convergence over a few million years, the only remaining parameter to test is the angle of the Wadati-Beniofl zone. Shiono et al. [1980] noted a change in the angle of subduction from $40^{\circ}$ to $70^{\circ}$ at about $150 \mathrm{~km}$ to the west of the Ryukyu trench. Assuming a 5 $\mathrm{cm} / \mathrm{s}$ convergence rate, the change of slope could have occurred 3 m.y. ago which is before the second rifting phase started.

The work we have reported on in this paper alters our views on the geology and evolution of the Okinawa Trough. Al- 

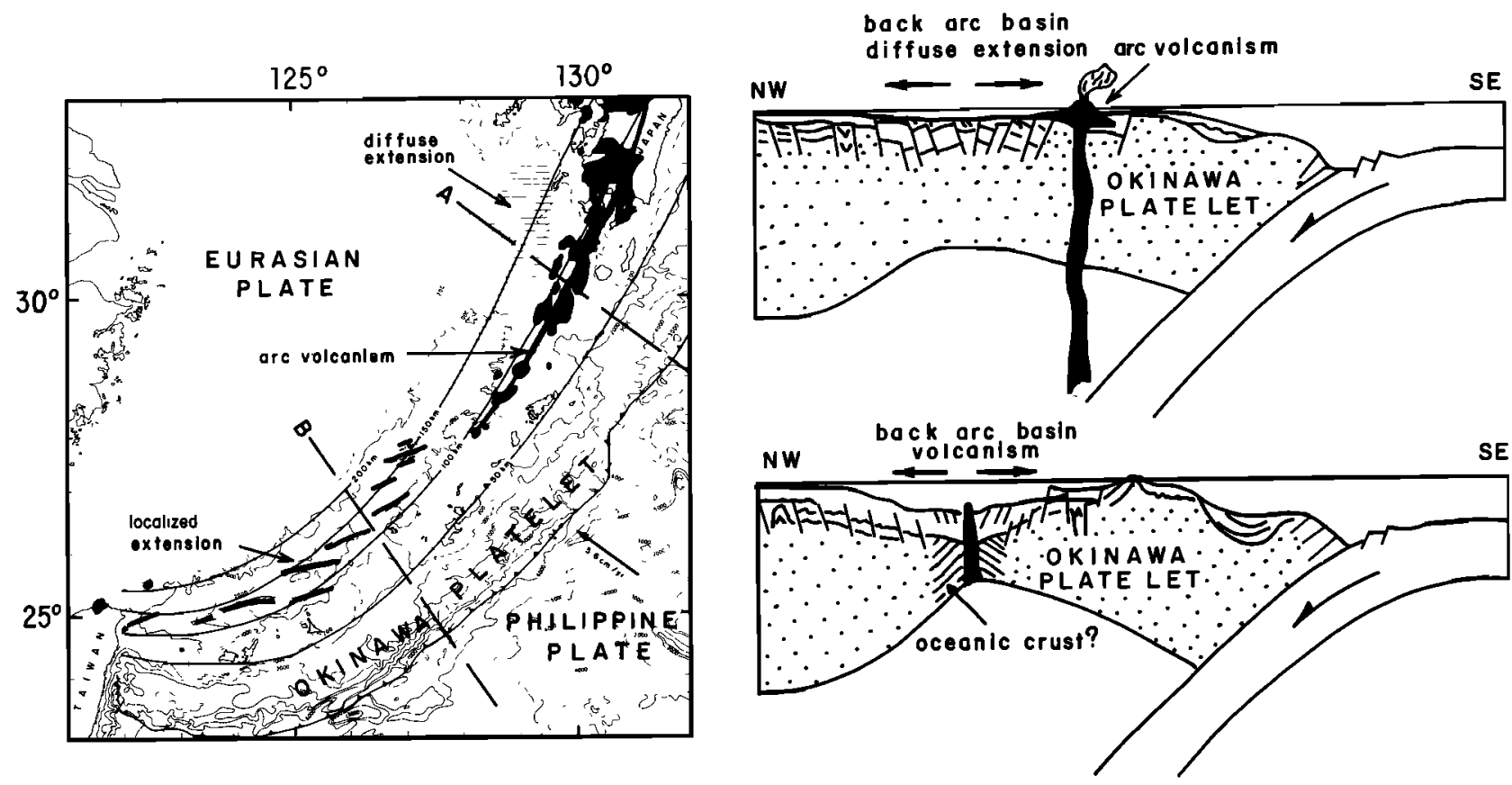

Fig. 16. Map of the Okinawa Trough region showing the position of the trench, the present-day active volcanic arc, and the axes of depressions and elongated ridges of the middle and southern Okinawa Trough. Depths of the WadatiBenioff zone are from Eguchi and Uyeda [1983]. Cross sections of the Okinawa platelet through the northern and southern Okinawa Trough.

though it is difficult, at the present stage, to favor any particular mechanism for the origin of tensional forces in the arc and back arc basin systems, the quantification of the pattern of extension, rifting, and spreading history limit the choice among the different possible alternatives which have been proposed.

We consider that it is now established that back arc volcanism was initiated in the southernmost portion of $、$ the trough and then moved northward. This migration was próbably accompanied by the shutting down of volcanic activity along the adjacent portions of the arc. Thus arc and back arc basin volcanism seems to be associated in a mutually exclusive manner such that cessation of volcanic activity along the arc occurs during a simultaneous northeastward extension of back arc spreading. This interplay of arc and back arc activity and the existence of several tectonic phases during the formation and evolution of the back arc basin over a short period of time are probably linked to changes in the parameters of plate

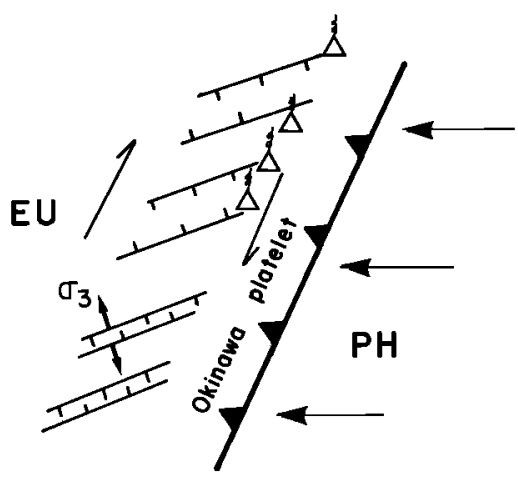

Fig. 17. General plate schematic diagram showing the extensional strike-slip motion of the Okinawa platelet with respect to Eurasia (EU). PH, Philippıne sea plate. convergence. We will need information on the deep structure of the arc and back arc basin to match these observations. The Okinawa Trough may be a good target for detailed refraction studies and drilling.

Acknowledgments. We are especially indebted to the captain and crew of the R/V Jean Charcot of Institut Français de Recherche pour l'Exploitation de la Mer (IFREMER), who greatly helped in the acquisition of geophysical and geological data during the POP 1 cruise. Many ideas were improved during discussions with Seiya Uyeda. James Hawkins, Janet Morton, David Needham, Brian Taylor, and Seiya Uyeda carefully reviewed the manuscript and offered helpful suggestions. IFREMER contribution 93.

\section{REFERENCES}

Andrews, D. J., and N. H. Sleep, Numerical modeling of tectonic flow behind island arcs, Geophys. J. R. Astron. Soc., 38, 237-252, 1974.

Bibee, L. D., G. G. Shor, and R. S. Lu, Inter-arc spreading in the Mariana Trough, Mar. Geol., 35, 183-197, 1980.

Charvet, J., and $\mathrm{O}$. Fabbri, Vue générale sur l'orogénèse Shimanto et l'evolution tertiaire du Japon Sud-Ouest, Bull. Soc. Geol. Fr., in press, 1987.

Chase, C. G., Extension behind island arcs and motions relative to hotspots, J. Geophys. Res., 83, 5385-5387, 1978.

Chenet, P.-Y., B. Coletta, J. Letouzey, G. Desforges, E. Ousset, and E. Zaghloul, Structures associated with extensional tectonics in the Suez rift, J. Geol. Soc. London, in press, 1987.

Cyaden Scientific Team (P. Choukroune, B. Auvray, J. Francheteau, J.-C. Lépine, F. Arthaud, J.-P. Brun, J.-M. Auzende, B. Sichler, and Y. Khobar), Tectonics of the westernmost Gulf of Aden and the Gulf of Tadjoura from submersible observations, Nature, 319, 396$400,1986$.

Davagnier, M., B. Marsset, J.-C. Sibuet, J. Letouzey, and J.-P. Foucher, Mécanismes actuels d'extension dans le bassin d'Okinawa, Bull. Soc. Geol. Fr., 8(3), 525-531, 1987.

Eguchi, T., and $S$. Uyeda, Seismotectonics of the Okinawa Trough and Ryukyu Arc, Mem. Geol. Soc. China, 5, 189-210, 1983.

Emery, K. O., Y. Hayashi, T. W. C. Hilde, K. Kobayashi, J. H. Koo, C. Y. Meng, H. Niino, J. H. Osterhagen, L. M. Reynolds, J. M. Wageman, C. S. Wang, and S. J. Yang, Geological structure and some water characteristics of the East China Sea and Yellow Sea, 
ECAFE Tech. Bull. 2, pp. 3-43, Econ. Comm. for Asia and the Far East, 1969.

Foucher, J.-P., X. Le Pichon, and J.-C. Sibuet, The ocean-continent transition in the uniform stretching model: Role of partial melting in the mantle, Philos. Trans. R. Soc. London, Ser. A, 305, 27-43, 1982.

Froidevaux, C., S. Uyeda, and M. Uyeshima, Island arc tectonics, Tectonophysics, in press, 1987.

Hasebe, K., N. Fujii, and S. Uyeda, Thermal processes under island arcs, Tectonophysics, 10, 335-355, 1970.

Hayes, D. E., R. E. Houtz, R. D. Jarrard, C. L. Mrozowski, and T. Watanabe, Crustal structure, 1 sheet, scale $1: 6,442,194$, in $A$ Geophysical Atlas of the East and Southeast Asian Seas, Map Chart Ser. MC 25, edited by D. E. Hayes, Geological Society of America, Boulder, Colo., 1978.

Herman, B. M., R. N. Anderson, and M. Truchan, Extensional tectonics in the Okinawa Trough, Geological and Geophysical Investigations of Continental Margins, edited by J. S. Watkins, L. Montadert, and P. W. Dickinson, Mem. Am. Assoc. Pet. Geol., 29, 199$208,1978$.

Hilde, T. W. C., C.-S. Lee, and D. E. Vander Zouwen, Tectonic and sedimentation history of Okinawa Trough: Implications for development of the East China and Yellow seas, paper presented at Korea-U.S. Conference on the Yellow Sea, June 1984.

Honza, E., Ruykyu Island (Nansei Shoto) Arc, GH 75-1 and GH 75-5 cruises, report, Geol. Surv. of Jpn., Tokyo, 1978.

Honza, E., Evolution of arc volcanism related to marginal sea spreading and subduction at trench, in Arc Volcanism: Physics and Tectonics, edited by D. Shimozuru and I. Yokoyama, pp. 177-189, Terra Scientific, Tokyo, 1983.

Jin, X., P. Yu, M. Lin, C. Li, and H. Wang, Preliminary study on the characteristics of crustal structure in the Okinawa Trough (in Chinese with English abstract), Oceanol. Limnol. Sin., 14(2), 105116, 1983.

Jurdy, D. M., and M. Stefanick, Flow models for back-arc spreading, Tectonophysics, 99, 191-206, 1983.

Karig, D. E., Origin and development of marginal basins in the western Pacific, J. Geophys. Res., 76, 2542-2561, 1971.

Katsumata, M., and L. Sykes, Seismicity and tectonics of the western Pacific: Izu-Mariana-Caroline and Ryukyu-Taiwan regions, J. Geophys. Res., 76, 5923-5948, 1969.

Kimura, M., Back-arc rifting in the Okinawa Trough, Mar. Pet. Geol., 2, 222-240, 1985.

Kimura, M., N. Isezaki, M. Furukawa, and T. Ishikawa, Geomagnetic anomalies in the middle Okinawa Trough, Bull. Geogr. Soc. Jpn., $94,155-169,1985$.

Lee, C. S., G. G. Shor, Jr., L. D. Bibee, R. S. Lu, and T. Hilde, Okinawa Trough: Origin of a back-arc basin, Mar. Geol., 35, 219 $241,1980$.

Le Pichon, X., and J.-C. Sibuet, Passive margins: A model of formation, J. Geophys. Res., 86, 3708-3710, 1981.

Le Pichon, X., P. Huchon, and E. Barrier, Pangea, Geoid and the evolution of the western margin of the Pacific Ocean, in Formation of Active Ocean Margins, edited by N. Nasu et al., pp. 3-42, Terrapub, Tokyo, 1985.

Letouzey, J., and M. Kimura, Okinawa Trough genesis: Structure and evolution of a back-arc basin developed in a continent, Mar. Pet. Geol., 2, 111-130, 1985.

Letouzey, J., and M. Kimura, The Okinawa Trough: Genesis of a back-arc basın developing along a continental margin, Tectonophysics, 125, 209-230, 1986.

Lu, K. S., J. J. Pan, and T. C. Lee, Heat flow in the southwestern Okinawa Trough, Earth Planet. Sci. Lett., 55, 299-310, 1981.

Minear, J. W., and M. N. Toksöz, Thermal regime of a downgoing slab and new global tectonics, $J$. Geophys. Res., 75, 1397-1419, 1970.

Molnar, P., and T. Atwater, Interarc-spreading and Cordilleran tectonics as alternates related to the age of subducted oceanic lithosphere, Earth Planet. Sci. Lett., 41, 330-340, 1978.

Montadert, L., O. de Charpal, D. Roberts, P. Guennoc, and J.-C. Sibuet, Northeast Atlantic passive continental margins: Rifting and subsidence processes, in Deep Drilling Results in the Atlantic Ocean: Conttnental Margins and Paleoenvironment, Maurice Ewing Ser., vol. 3, edited by M. Talwani, W. Hay, and W. B. F. Ryan, pp. 154-186, AGU, Washington D. C., 1979.

Murauchi, S., M. Den, S. Asano, H. Hotta, T. Yoshii, T. Asanuma, K.
Hagiwara, K. Ichikawa, R. Sato, W. J. Ludwig, J. I. Ewing, N. T. Edgar, and R. E. Houtz, Crustal structure of the Philippine Sea, $J$. Geophys. Res., 73, 3143-3171, 1968.

Nagumo, S., H. Kinoshita, J. Kasahara, T. Ouchi, H. Tokuyama, T. Asamuma, S. Koresawa, and H. Akiyoshi, Report on DELP 1984 cruises in the Middle Okinawa Trough, part II, Seismic structural studies, Bull. Earthquake Res. Inst. Univ. Tokyo, 61, 167-202, 1986.

Nash, D. F., The geological development of the north Okinawa trough area from Neogene times to Recent, J. Jpn. Assoc. Pet. Technol., 44, 121-133, 1979.

Seno, T., The instantaneous rotation vector of the Philippine Sea plate relative to the Eurasian plate, Tectonophysics, 42, 209-226, 1977.

Seno, T., and S. Maruyama, Paleogeographic reconstruction and origin of the Philippine Sea, Tectonophysics, 102, 53-54, 1984.

Shiono, K., T. Mikumo, and Y. Ishikawa, Tectonics of the KyushuRyukyu Arc as evidenced from seismicity and focal mechanism of shallow to intermediate-depth earthquakes, J. Phys. Earth, 28, $17-43,1980$.

Sibuet, J.-C., J. Letouzey, B. Marsset, M. Davagnier, J.-P. Foucher, H. Bougault, L. Dosso, R. Maury, and J.-L. Joron, Tectonic evolution and volcanism of Okinawa Trough, paper presented at the 4th Circum-Pacific Conference, Circum-Pacific Counc. for Energy and Miner. Resour. Singapore, Aug. 17-22, 1986.

Sleep, N. H., and M.N. Toksöz, Evolution of marginal basins, Nature, 233, 548-550, 1971.

Sun, S. C., The Tertiary basins of off-shore Taiwan, paper presented at ASCOPE Conference, ASCOPE, Manila, 1981.

Toksöz, M. N., and P. Bird, Formation and evolution of marginal basins and continental plateaus, in Island Arcs, Deep Sea Trenches and Back-Arc Basins, Maurice Ewing Ser., vol. 1, edited by $\mathbf{M}$. Talwani and W. C. Pitman III, pp. 379-393, AGU, Washington, D. C., 1977.

Uyeda, S., Some basic problems in trench-arc-back-arc-system, in Island Arcs, Deep Sea Trenches and Back-Arc Basins, Maurice Ewing Ser., vol. 1, edited by M. Talwani and W. C. Pitman, III, pp. 1-14, AGU, Washington, D. C., 1977.

Uyeda, S., Subduction zones: Their diversity, mechanism and human impacts, GeoJournal, 8, 381-406, 1984.

Uyeda, S., and H. Kanamori, Back-arc opening and the mode of subduction, J. Geophys. Res., 84, 1049-1061, 1979.

Uyeda, S., S. Nagumo, and T. W. C. Hilde, Okinawa Trough-An early stage of continental margin rifting, paper presented at 1985 Geodynamics Symposium on Intraplate Deformation: Characteristics, Processes, and causes, Tex. A\&M Univ., College Station, April 25-26, 1985a.

Uyeda, S., M. Kimura, T. Tanaka, J. Kaneoka, Y. Kato, and I. Kushiro, Spreading center of the Okinawa Trough (in Japanese with English abstract), Tech. Rep. JAMSTEC, Spec. Issue 16, pp. 123142, Jpn. Mar. Sci. and Technol. Cent., Tokyo, location, $1985 b$.

Vander Zouwen, D. E., Structure and evolution of Southern Okinawa Trough, thesis, 94 pp., Univ. of Tex. A\&M, College Station, 1985.

Viallon, C., P. Huchon, and E. Barrier, Opening of the Okinawa basin and collision in Taiwan: A retreating trench model with lateral anchoring, Earth Planet. Sci. Lett., 80, 145-155, 1986.

Wageman, J. M., T. W. C. Hilde, and K. O. Emery, Structural framework of East China Sea and Yellow Sea, Am. Assoc. Pet. Geol. Bull., $54,1611-1643,1970$.

Wanatabe, T., M. G. Langseth, and R. N. Anderson, Heat flow in back-arc basins of the western Pacific, in Island Arcs, Deep Sea Trenches and Back-Arc Basins, Maurice Ewing Ser., vol. 1, edited by M. Talwani and W. C. Pitman III, AGU, Washington, D. C., 1977.

Watts, A. B., J. K. Weissel, and R. L. Larson, Sea-floor spreading in marginal basins of the western Pacific, Tectonophysics, 37, 167-181, 1976.

Weissel, J. K., Evolution of the Lau basin by the growth of small plates, in Island Arcs, Deep Sea Trenches and Back-Arc Basins, Maurice Ewing Ser., vol. 1, edited by M. Talwani and W. C. Pitman III, pp. 429-436, AGU, Washington, D. C., 1977

Yamano, M., S. Uyeda, J.-P. Foucher, and J.-C. Sibuet, Heat flow anomaly in the middle Okinawa trough, Tectonophysics, in press, 1987.

Yasul, M., D. Epp, K. Nagasuka, and T. Kishii, Terrestrial heat flow in the seas around Nansei-Shoto (Ryukyu Islands), Tectonophysics, $10,225-234,1970$. 
F. Barbier, Laboratoire de Géodynamique, T 25-15, 1 er étage, Paris 6, 4 place Jussieu, 75005 Paris, France.

J. Charvet, Sciences de la Terre, Université d'Orléans, 45067 Orléans Cédex, France.

Chiao, L.-Y., Institute of Oceanography, National Taiwan University, Taipe1, Taiwan, Republic of China.

J.-P. Foucher and J.-C. Sibuet, IFREMER Centre de Brest, BP 337, 29273 Brest Cédex, France.

T. W. C. Hilde, Geodynamics Research Institute, Texas A\&M University, College Station, Texas 77843.

M. Kimura, University of the Ryukyus, Senbaru 1, Nishihara, Okinawa 903-01, Japan.
J. Letouzey, IFP, 1 à 4 avenue de Bois Préau, 92506 RueilMalmaison Cédex, France.

B. Marsset and J.-F. Stéphan, G.I.S. Océanologie et Dynamique, U.B.O., 6 avenue Le Gorgeu, 29283 Brest Cédex, France.

C. Muller, 1 rue Martignon, 92500 Rueil-Malmaison, France.

(Received April 4, 1986;

revised June 9, 1987;

accepted July 8, 1987.) 